OAK RIDGE NATIONAL LABORATORY

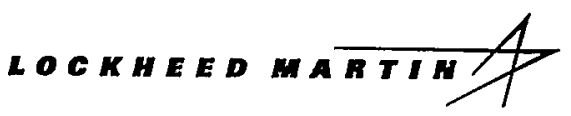

RECEVED

\author{
FFR 112000 CRADA Final Report \\ U STI for \\ CRADA Number ORNL95-0327
}

\section{MANUFACTURING OF NICKEL-BASE SUPERALLOYS WITH IMPROVED HIGH- TEMPERATURE PERFORMANCE}

C. G. McKamey, E. P. George, C. T. Liu J. A. Horton, and C. A. Carmichael Oak Ridge National Laboratory

R. L. Kennedy and W. D. Cao Allvac, an Allegheny Teledyne Company
Prepared by the Oak Ridge National Laboratory Oak Ridge, Tennessee 37831 managed by

Lockheed Martin Energy Research Corporation for the U. S. Department of Energy under contract DE-AC05-96OR22464 
This report has been reproduced from the best available copy.

Reports are available to the public from the following source.

National Technical information Service

5285 Port Royal Road

Springfield, VA 22161

Telephone 703-605-6000 (1-800-553-6847)

TDD 703-487-4639

Fax 703-605-6900

E-mail orders @ ntis.fedworld.gov

Web site http://www.ntis.gov/ordering.htm

Reports are available to U.S. Department of Energy (DOE) employees, DOE contractors, Energy Technology Data Exchange (ETDE) representatives, and International Nuclear Information System (INIS) representatives from the following source.

Office of Scientific and Technical Information

P.O. Box 62

Oak Ridge, TN 37831

Telephone 423-576-8401

Fax 423-576-5728

E-mail reports@ adonis.osti.gov

Web site http://www.osti.gov/products/sources.html

Reports produced after January 1, 1996, are generally available via the DOE Information Bridge.

Web site $h$ ttp://www.doe.gov/bridge 


\section{DISCLAIMER}

This report was prepared as an account of work sponsored by an agency of the United States Government. Neither the United States Government nor any agency thereof, nor any of their employees, make any warranty, express or implied, or assumes any legal liability or responsibility for the accuracy, completeness, or usefulness of any information, apparatus, product, or process disclosed, or represents that its use would not infringe privately owned rights. Reference herein to any specific commercial product, process, or service by trade name, trademark, manufacturer, or otherwise does not necessarily constitute or imply its endorsement, recommendation, or favoring by the United States Government or any agency thereof. The views and opinions of authors expressed herein do not necessarily state or reflect those of the United States Government or any agency thereof. 


\section{DISCLAIMER}

\section{Portions of this document may be illegible in electronic image products. Images are produced from the best available original document.}




\section{CRADA Final Report \\ for}

CRADA Number ORNL95-0327

\section{MANUFACTURING OF NICKEL-BASE SUPERALLOYS WITH IMPROVED HIGH-TEMPERATURE PERFORMANCE}

C. G. McKamey, E. P. George, C. T. Liu, J. A. Horton, and C. A. Carmichael

Oak Ridge National Laboratory

R. L. Kennedy and W. D. Caó

Allvac, an Allegheny Teledyne Company

Prepared by the

Oak Ridge National Laboratory

Oak Ridge, Tennessee 37831

managed by

Lockheed Martin Energy Research Corporation

for the

U.S. Department of Energy

under contract DE-AC05-96OR22464

APPROVED FOR PUBLIC RELEASE

UNLIMITED DISTRIBUTION 
. 


\section{CONTENTS}

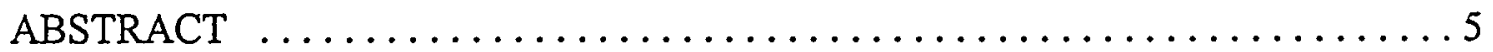

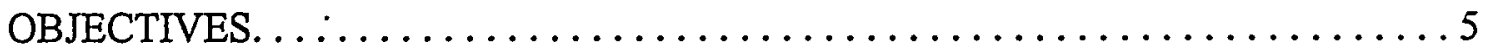

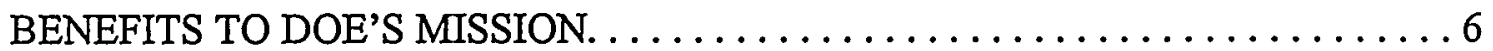

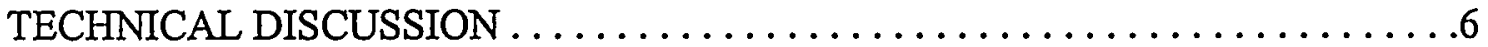

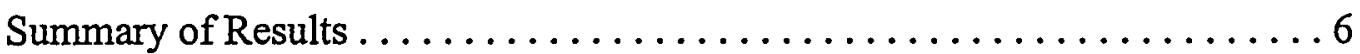

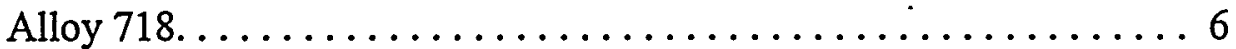

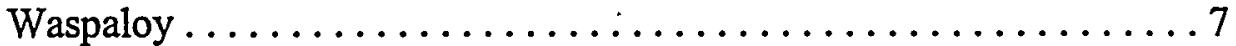

Technical Details . . . . . . . . . . . . . . . . .

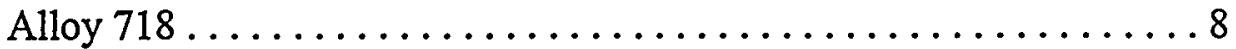

Experimental Procedures . . . . . . . . . . . . 8

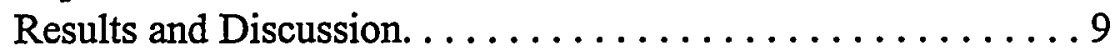

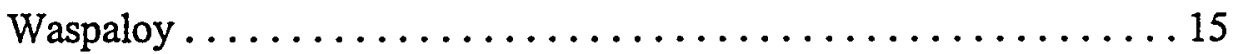

Experimental Procedures ................. 15

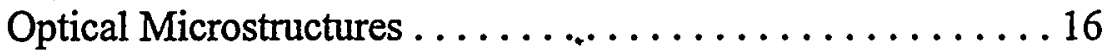

Creep and Creep-Rupture Testing . . . . . . . . . . 18

Slow-Strain-Rate Testing . . . . . . . . . . . . . 25

General Discussion ..................... 26

INVENTIONS. . . . . . . . . . . . . . . . . . . . . . . . . 28

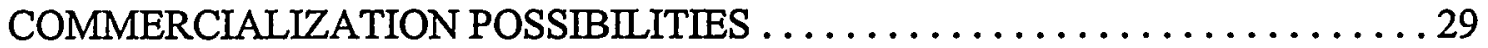

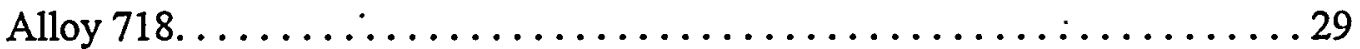

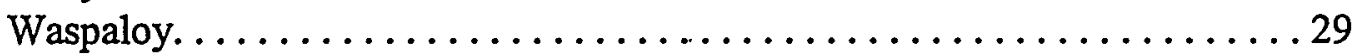

PLANS FOR FUTURE COLLABORATIONS $\ldots \ldots \ldots \ldots \ldots \ldots \ldots \ldots \ldots \ldots$

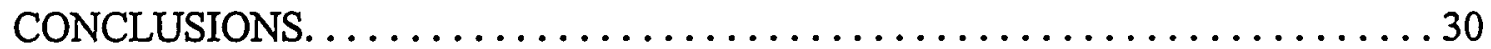

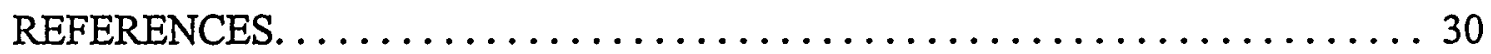




\title{
MANUFACTURING OF NICKEL-BASE SUPERALLOYS WITH IMPROVED HIGH-TEMPERATURE PERFORMANCE
}

\author{
C. G. McKamey, E. P. George, C. T. Liu, J. A. Horton, C. A. Carmichael, \\ R. L. Kennedy and W. D. Cao
}

\begin{abstract}
This report summarizes the results of research conducted as part of CRADA ORNL95-0327 between Oak Ridge National Laboratory and Teledyne Allvac (now Allvac, an Allegheny Teledyne Co.). The objective was to gain a better understanding of the role of trace elements in nickel-based superalloys, with the ultimate goal of enhancing performance without significantly increasing production cost. Two model superalloys, IN 718 and Waspaloy, were selected for this study, and the synergistic effects of $\mathrm{P}$ and $\mathrm{B}$ additions on creep and stress rupture properties were determined. Wherever possible the underlying physical mechanisms responsible for the observed effects were investigated.
\end{abstract}

\section{OBJECTIVES}

Nickel-base superalloys are state-of-the-art materials for high-temperature structural applications in advanced engines, petrochemical systems, and other energy conversion systems. The effects of some trace elements such as $\mathrm{P}$ in Ni-base superalloys appear to have been historically misunderstood. Specifications for Ni-base superalloys have typically restricted $P$ to a low level which, in some cases, causes an increase in production cost. Preliminary results from Allvac indicated that some materials actually benefit from purposeful additions of $P$ beyond the usual limit. Furthermore, the effect may be expanded by careful control of other trace elements, including boron and carbon. The objective of this CRADA between Oak Ridge National Laboratory (ORNL) and Teledyne Allvac (now Allvac, an Allegheny Teledyne Company) was to gain a

*This work was supported through a CRADA with Allvac, an Allegheny Teledyne Company, Monroe, NC, sponsored by the Laboratory Technology Research Program, Office of Science, U.S. Department of Energy, under contract DE-AC05-96OR22464 with Oak Ridge National Laboratory, managed by Lockheed Martin Energy Research Corporation. 
better understanding of the role of trace elements and thereby enhance performance without significantly increasing production cost. It was anticipated that careful control of trace elements could extend the creep rupture life of superalloy structural members by more than an order of magnitude.

Emphasis in the present study was on understanding possible synergistic effects among the minor alloying additions. Two model superalloys, IN 718 and Waspaloy, were selected for this study of microalloying effects. In alloy $718, \mathrm{P}$ and $\mathrm{B}$ have a positive synergism [1-3], with the best improvement in stress-rupture life observed when both elements are present at their respective optimum levels (which are significantly higher than their levels in commercial heats). In Waspalloy, on the other hand, the longest stress-rupture life is obtained when $B$ is added at its optimum level but $P$ is kept at the lowest possible level [1-3]. At higher $P$ concentrations (e.g., at the typical $P$ level found in commercial heats of Waspalloy), the beneficial effect of $B$ is not as great.

\section{BENEFITS TO DOE'S MISSION}

This CRADA project relates to three major missions of DOE: (1) science and technology, (2) energy resources and energy efficiency, and (3) economic productivity. Nickel-base superalloys are state-of-the-art materials for high-temperature structural applications in advanced engines, petrochemical systems, and other energy conversion systems. The research performed under this CRADA will help in the development of upgraded superalloys with improved performance and temperature capability. Careful control of microalloying additions was shown to result in as much as a ten-fold increase in the stress-rupture life and creep strength of superalloys. Thus, for the same rupture life, stress or temperature can be increased, resulting in improved efficiency and energy conservation. Additionally, the results of this CRADA project will help develop general scientific principles for the design of other high-temperature structural materials.

\section{TECHNICAL DISCUSSION}

\section{Summary of Results}

\section{Alloy 718}

Detailed results of the investigations on IN718 have been published in refs. [47]. The principal results are summarized here. Phosphorus significantly increased 
stress rupture life, independent of boron. However, B, which is widely acknowledged as improving stress rupture properties, was nearly ineffective when $P$ was held to very low levels $(=0.0016 \mathrm{wt} \%)$. When optimum levels of both elements were present, rupture life far exceeded the maximum achieved by either element acting alone. Over the entire composition range investigated, rupture life varied by more than ten fold. Rupture ductilities were unchanged, but creep testing showed a decrease in the steady state creep rate of up to ten fold. Both $\mathrm{P}$ and $\mathrm{B}$ were found on the grain boundaries of these samples, but fracture was completely transgranular. There was no evidence that the stability of the $\gamma^{\prime}$ or $\gamma^{\prime \prime}$ precipitates changed with $\mathrm{P}$ and $\mathrm{B}$ additions, or that these elements segregated to the particle interfaces. Other properties, including room and elevated temperature $\left(650^{\circ} \mathrm{C}\right)$ tensile strength, low cycle fatigue strength, and weldability were either unchanged or slightly improved by the $\mathrm{P}+\mathrm{B}$ additions.

\section{Waspaloy}

An entirely different behavior for $P$ and its interaction with $B$ was observed in Waspaloy [1-3]. Optimum stress rupture life was achieved at the lowest $P$ content. At this $\mathrm{P}$ level, $\mathrm{B}$ was a very effective strengthener, with the longest life observed with addition of $0.016 \mathrm{wt} \% \mathrm{~B}$. If $\mathrm{P}$ is present at levels of $0.006 \mathrm{wt} \%$ or higher (which is close to typical for commercial Waspaloy), the strengthening effect of $B$ appears to saturate at $0.005 \mathrm{wt} \%$ (also typical commercial content) and further increases in B content result in no, or an insignificant, increase in life. Again, over the entire compositional range studied, rupture life varied by ten fold. Broken stress rupture specimens revealed a totally intergranular failure mode for Waspaloy under these conditions.

Creep tests and slow-strain-rate tensile tests were performed on Waspaloy containing different levels of the microalloying additions $\mathrm{B}$ and $\mathrm{P}$ and the detailed results are reported below. Both strength and ductility were affected by the amount of $B$ and $\mathrm{P}$ present in Waspaloy. Creep strength was highest in the high- $\mathrm{B}$ low-P alloy and lowest in the high-B high-P alloy, with the high-purity and commercial-purity alloys generally falling in between. (This trend became clearer the higher the test temperature.) Interpretation of the trace element effects was complicated by the presence of bands of larger grain size in most of the alloys tested. The high-purity alloy was the worst in this regard, with as much as $50 \%$ of its cross-sectional area occupied by larger grains. In general, when grain-boundary sliding is the dominant deformation mechanism in creep, fine grain size alloys are weaker than coarse grain size alloys. In the present study, however, the high-purity alloy (with the largest grains) was weaker than 
the high-B low-P alloy with finer grains, suggesting that intra-granular processes of dislocation locking (directly by trace-element atmospheres or indirectly by the trace elements altering the vacancy concentrations) may be more important than grainboundary sliding. A similar conclusion was drawn in the case of IN718 since B and P were found not to alter the coarsening rate of the $\gamma$ " precipitates in that alloy. An unexplained difference is why the dislocation locking (if, indeed that is the strengthening mechanism) is most effective when B and P act together in IN718 but when B acts by itself in Waspaloy.

Ductility was lowest in the high-purity Waspaloy with the largest grain size (both in creep tests and in slow-strain rate tensile tests), which is not surprising given that fracture in Waspaloy generally occurs intergranularly. Ductility improvements occurred either when $\mathrm{B}$ was added by itself or when $\mathrm{B}$ and $\mathrm{P}$ were added together. In contrast, strength improvements occurred when B was added by itself, not when it was added in conjunction with $P$. Since poor ductility and low strength can both be lifelimiting factors in high-temperature structural alloys, it is clear that the high-B low-P modification of Waspaloy is optimal.

\section{Technical Details}

\section{Alloy 718}

Experimental Procedures - Three 718-type alloys, with Allvac designations of G988, G457, and G727, were vacuum induction melted as $23-\mathrm{kg}$ heats and cast as 70 $\mathrm{mm}$ diameter electrodes. The electrodes were further refined by vacuum arc remelting to $100 \mathrm{~mm}$ diameter ingots which were homogenized for $16 \mathrm{~h}$ at $1190^{\circ} \mathrm{C}$ and rolled to $15 \mathrm{~mm}$ diameter bars within the temperature range of $1040-920^{\circ} \mathrm{C}$. The wrought bars were then given the following heat treatment: a solution treatment at $954^{\circ} \mathrm{C}$ for $1 \mathrm{~h}$, followed by an air cool to and aging at $718^{\circ} \mathrm{C}$ for $8 \mathrm{~h}$, a furnace cool at $55^{\circ} \mathrm{C} / \mathrm{h}$ to $621^{\circ} \mathrm{C}$ where they were held for $8 \mathrm{~h}$, followed by an air cool to room temperature. Their compositions are listed in Table I. G457 is the current commercial alloy; G988 is a high purity alloy containing essentially no $\mathrm{P}$ or $\mathrm{B}$; and the alloy 718 with the optimum concentrations of $\mathrm{P}$ and $\mathrm{B}$ is designated as $\mathrm{G} 727$.

Creep-rupture specimens with a gage of $3.18 \mathrm{~mm}$ diameter and $17.8 \mathrm{~mm}$ in length were machined from the as-heat-treated bars and tested without further heat treatment. Creep rupture tests were conducted in air using lever-arm creep machines with either a 5:1 or.20:1 load ratio. Tests were conducted at various stresses at tempera- 


\begin{tabular}{|c|c|c|c|}
\hline \multicolumn{3}{|c|}{ Table I. Composition of 718-Based Alloys } \\
\hline \multirow{3}{*}{ Element } & \multicolumn{3}{|c|}{ Composition (wt\%) } \\
\cline { 2 - 4 } & G-988 & G-457 & G-727 \\
& (high purity) & (commercial grade) & Balance \\
(microalloyed) \\
\hline $\mathrm{Ni}$ & Balance & Balance & 19.26 \\
$\mathrm{Fe}$ & 19.35 & 19.38 & 17.90 \\
$\mathrm{Cr}$ & 17.9 & 17.83 & 5.05 \\
$\mathrm{Nb}+\mathrm{Ta}$ & 5.22 & 5.06 & 2.85 \\
$\mathrm{Mo}$ & 2.86 & 2.87 & 0.92 \\
$\mathrm{Ti}$ & 0.92 & 0.92 & 0.58 \\
$\mathrm{Al}$ & 0.47 & 0.63 & 0.01 \\
$\mathrm{Si}$ & 0.01 & 0.1 & 0.0018 \\
$\mathrm{Mg}$ & 0.0011 & 0.0017 & 0.002 \\
$\mathrm{~N}$ & 0.0015 & 0.0037 & 0.0004 \\
$\mathrm{~S}$ & 0.0008 & 0.0004 & 0.009 \\
$\mathrm{C}$ & 0.008 & 0.031 & 0.011 \\
$\mathrm{~B}$ & $<0.001$ & 0.004 & 0.022 \\
$\mathrm{P}$ & $<0.001$ & 0.006 & \\
\hline
\end{tabular}

tures of $593\left(1100^{\circ} \mathrm{F}\right), 649\left(1200^{\circ} \mathrm{F}\right), 677\left(1250^{\circ} \mathrm{F}\right)$, and $704^{\circ} \mathrm{C}\left(1300^{\circ} \mathrm{F}\right)$. Some of the specimens were tested to rupture, while the stress was incrementally increased on other specimens in order to obtain minimum creep rates at several different stresses with the same specimen. The secondary stage minimum creep rates were measured from the straight-line portions of the creep curves and were used to determine the stress exponents and activation energies for creep. For purposes of comparison, the data were plotted according to the simple Arrhenius equation

$$
\dot{\varepsilon}=\mathrm{A} \sigma^{\mathrm{n}}\left(\mathrm{e}^{-\mathrm{Q} / \mathrm{RT}}\right) \text {, }
$$

where $\dot{\varepsilon}$ is the minimum creep rate, $A$ is a constant, $\sigma$ is the applied stress, $n$ is the stress exponent, $Q$ is the activation energy for creep, $R$ is the gas constant, and $T$ is the absolute temperature. Although typically only one test was conducted at each particular - temperature and stress, many tests at various stresses were conducted at each temperature in order to produce enough data for an accurate determination of the stress exponents and activation energies.

Microstructures of the alloys were studied using optical and scanning electron microscopy (SEM) techniques. Specimens were metallographically polished through $0.5 \mu \mathrm{m}$ diamond and then were etched in a solution of 4 parts $\mathrm{HCl}$ and 1 part $\mathrm{HNO}_{3}$.

Results and Discussion - The microstructures of all three alloys viewed optically and by SEM were determined to be comparable, with average grain sizes in the 
7-10 $\mu \mathrm{m}$ range. The typical microstructure is shown in Fig. 1. No in-depth analyses of the volume fraction, size, or distribution of the orthorhomic $\mathrm{Ni}_{3} \mathrm{Nb} \delta$ phase (almost always present in aged alloy 718 ) were performed, but visibly no significant differences were observed either before or after creep testing. An earlier study using transmission electron microscopy also showed that, although the $\gamma^{\prime}\left[\mathrm{Ni}_{3}(\mathrm{Al}, \mathrm{Ti}), \mathrm{L}_{2}\right]$ and $\gamma^{\prime \prime}\left(\mathrm{Ni}_{3} \mathrm{Nb}\right.$, $\mathrm{DO}_{22}$ ) precipitates tend to coarsen during long-term aging at $704^{\circ} \mathrm{C}$, there is no measurable difference in the stability of these precipitates in the high-purity versus modified 718 alloys after creep testing or long term aging [6]. Atom probe field ion microscopy was used to determine that phosphorus and boron did not segregate to $\gamma^{\prime}-\gamma$ or $\gamma^{\prime \prime}-\gamma$ boundaries, but instead segregated to the $\gamma-\gamma$ grain boundaries $[6,8]$.

Table II lists the results for the creep-rupture tests that were allowed to proceed to failure. Typical creep curves for the three alloys tested at $704^{\circ} \mathrm{C}$ and $483 \mathrm{MPa}(70$ ksi) are shown in Fig. 2. The microalloyed G727 alloy clearly shows superior creep resistance compared to the other two alloys. For example, for the temperature and stress combination shown in Fig. 2, the minimum creep rates for the high-purity G988 and commercial grade G457 specimens were $8.3 \times 10^{-7} \mathrm{~s}^{-1}$ and $1.7 \times 10^{-7} \mathrm{~s}^{-1}$, respectively, while the P/B-modified G727 alloy specimen had a minimum creep rate of $1.7 \times 10^{-8} \mathrm{~s}^{-1}$. Creep life was increased from approximately $12 \mathrm{~h}$ in the high-purity G988 alloy to 183 $h$ in alloy G727. In other words, at $704^{\circ} \mathrm{C}$ and $483 \mathrm{MPa}$, controlled additions of $\mathrm{P}$ and $\mathrm{B}$ resulted in almost two orders of magnitude improvement in the minimum creep rate and 15 times increase in the creep life over the alloy with essentially no $P$ and $B$. These results compare favorably with and further substantiate earlier test results $[1,3,9]$.

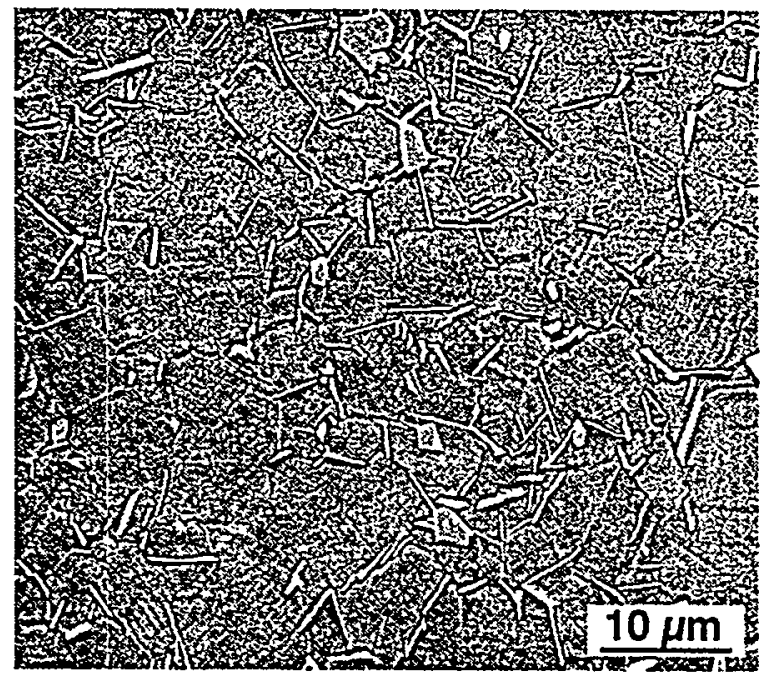

Fig. 1. A SEM micrograph showing the typical microstructure (in this case, of the G727 alloy) of the 718-type alloys used in this study. 


\begin{tabular}{|c|c|c|c|c|c|c|}
\hline Alloy & $\begin{array}{l}\text { Specimen } \\
\text { No. }\end{array}$ & $\begin{array}{l}\text { Test Temp. } \\
\left({ }^{\circ} \mathrm{C}\right)\end{array}$ & $\begin{array}{l}\text { Test Stress } \\
(\mathrm{MPa})(\mathrm{ksi})\end{array}$ & Life (h) & $\begin{array}{c}\text { Elongation } \\
(\%)\end{array}$ & $\begin{array}{l}\text { Min. Creep } \\
\text { Rate }\left(\mathrm{s}^{-1}\right)\end{array}$ \\
\hline $\begin{array}{l}\text { G988 (high } \\
\text { purity). }\end{array}$ & $\begin{array}{c}2 \\
1 \\
13 \\
9 \\
30\end{array}$ & 704 & $\begin{array}{l}379(55) \\
483(70) \\
552(80) \\
621(90) \\
690(100)\end{array}$ & $\begin{array}{c}37.0 \\
12.4 \\
8.5^{\mathrm{a}} \\
41.8 \\
24.5\end{array}$ & $\begin{array}{l}17.0 \\
25.7 \\
25.0^{\mathrm{a}} \\
17.0 \\
22.1\end{array}$ & $\begin{array}{l}1.9 \text { e-7 } \\
8.3 \text { e-7 } \\
9.7 \text { e-7 } \\
2.0 \text { e-7 } \\
3.3 \text { e-7 }\end{array}$ \\
\hline $\begin{array}{l}\text { G457 } \\
\text { (comm. } \\
\text { grade) }\end{array}$ & $\begin{array}{l}22 \\
37 \\
27 \\
31 \\
32 \\
21 \\
28\end{array}$ & $\begin{array}{r}704 \\
\\
677 \\
649\end{array}$ & $\begin{array}{l}483(70) \\
552(80) \\
621(90) \\
552(80) \\
621(90) \\
621(90) \\
690(100)\end{array}$ & $\begin{array}{r}31.7 \\
19.8 \\
7.5 \\
80.7 \\
32.8 \\
108.5 \\
107.6\end{array}$ & $\begin{array}{l}21.0 \\
25.8 \\
36.6 \\
20.5 \\
18.8 \\
26.3 \\
13.3\end{array}$ & $\begin{array}{l}1.7 \mathrm{e}-7 \\
2.8 \mathrm{e}-7 \\
6.0 \mathrm{e}-7 \\
7.8 \mathrm{e}-8 \\
3.9 \mathrm{e}-7 \\
1.9 \mathrm{e}-8 \\
2.8 \mathrm{e}-8\end{array}$ \\
\hline $\begin{array}{c}\text { G727 } \\
\text { (optimum } \\
\text { P\&B) }\end{array}$ & $\begin{array}{l}26 \\
12 \\
41 \\
29 \\
33\end{array}$ & $\begin{array}{l}704 \\
677 \\
649\end{array}$ & $\begin{array}{l}483(70) \\
586(85) \\
690(100) \\
690(100) \\
758(110)\end{array}$ & $\begin{array}{r}183.4 \\
46.5^{\mathrm{a}} \\
77.6 \\
1436.0 \\
98.5\end{array}$ & $\begin{array}{l}20.4 \\
17.5^{\mathrm{a}} \\
20.0 \\
14.5 \\
13.8\end{array}$ & $\begin{array}{l}1.7 \mathrm{e}-8 \\
1.3 \mathrm{e}-7 \\
1.4 \mathrm{e}-8 \\
2.4 \mathrm{e}-9 \\
2.8 \mathrm{e}-9\end{array}$ \\
\hline
\end{tabular}

aspecimens creep tested to beginning of necking, then cooled to near room temperature and ruptured in air by applying an overload. These specimens were then analyzed using TEM.

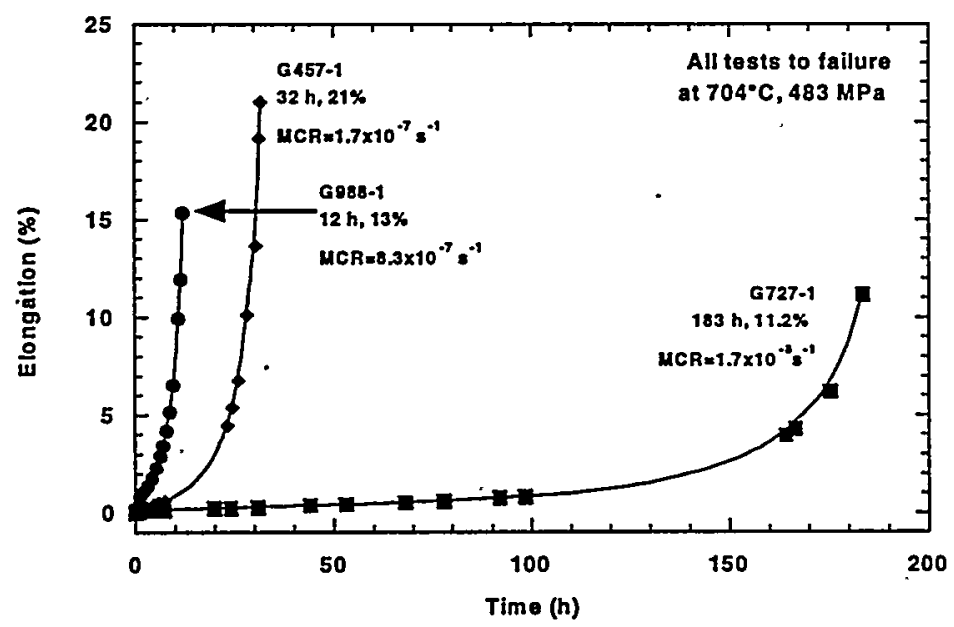

Fig. 2. Comparison of creep-rupture curves at $704^{\circ} \mathrm{C}$ and $483 \mathrm{MPa}(70 \mathrm{ksi})$ for the $\mathrm{G} 988$, G457, and G727 alloys.

As noted above, not all of the creep tests performed in this study were allowed to proceed to fracture; instead, many specimens were used to determine several minimum creep rates by incrementally increasing the stress. Using the Arrhenius equation, 
the activation energies for creep, $\mathrm{Q}$, and the stress exponents, $\mathrm{n}$, were determined and the results are presented in Table III. The activation energies for creep, illustrated for the G988 and G727 alloys in Fig. 3, were determined to increase in the inverse order as the minimum creep rates: approximately $99 \mathrm{kcal} / \mathrm{mole}$ for the high-purity $\mathrm{G} 988$ alloy, $144 \mathrm{kcal} / \mathrm{mole}$ for the commercial G457 alloy, and $240 \mathrm{kcal} / \mathrm{mole}$ for the P/B-modified G727 alloy. For the pure G988 alloy, the measured value for the creep activation energy is within the range of reported values for the activation energy for self diffusion in other Ni-based superalloys [10] and is higher than the activation energy for self diffusion in pure nickel $[11,12]$ (as would be expected in alloys compared to pure metals).

Under experimental conditions where the Arrhenius equation is valid, the value of the stress exponent, $n$, can be used to identify possible mechanisms controlling creep deformation as either diffusional creep $(n \sim 1)$, viscous dislocation glide $(n \sim 3)$, dislocation climb $(n \sim 4-5)$, or particle strengthening $(n \geq 6)[13,14]$. In the high-purity G988 alloy, as shown in Fig. 4, the stress exponent data showed a tendency for a shift

\begin{tabular}{|c|c|c|c|c|c|c|}
\hline \multirow{2}{*}{ Alloy } & \multicolumn{3}{|c|}{ Activation Energies } & \multicolumn{3}{|c|}{ Creep Exponents } \\
\hline & $\begin{array}{l}\text { Stress } \\
(\mathrm{MPa})\end{array}$ & $\begin{array}{l}\text { Temp. Range } \\
\qquad\left({ }^{\circ} \mathrm{C}\right)\end{array}$ & $\begin{array}{c}\mathrm{Q} \\
(\mathrm{kcal} / \mathrm{mol}-\mathrm{K})\end{array}$ & $\begin{array}{l}\text { Temp. } \\
\left({ }^{\circ} \mathrm{C}\right)\end{array}$ & $\begin{array}{c}\text { Stress Range } \\
(\mathrm{MPa})\end{array}$ & $\mathrm{n}$ \\
\hline $\begin{array}{c}\text { G988 (high } \\
\text { purity) }\end{array}$ & $\begin{array}{l}482.6 \\
551.6 \\
620.6\end{array}$ & $593-704$ & $\begin{array}{c}94 \\
93 \\
111\end{array}$ & $\begin{array}{l}704 \\
649 \\
593\end{array}$ & $\begin{array}{l}350-600 \\
200-350 \\
400-700 \\
200-400 \\
650-850 \\
450-650\end{array}$ & $\begin{array}{c}7.2 \\
2.0 \\
7.0 \\
2.5 \\
11.1 \\
1.9\end{array}$ \\
\hline & \multicolumn{2}{|c|}{ Average Q } & 99 & \multicolumn{2}{|c|}{$\begin{array}{r}\text { Range of } n \text { - low stresses } \\
- \text { high stresses }\end{array}$} & $\begin{array}{r}2-2.5 \\
7-11\end{array}$ \\
\hline $\begin{array}{l}\text { G457 (comm } \\
\text { grade) }\end{array}$ & $\begin{array}{l}413.7 \\
482.6 \\
551.6 \\
620.6\end{array}$ & $649-704$ & $\begin{array}{l}184 \\
135 \\
119 \\
136\end{array}$ & $\begin{array}{l}704 \\
677 \\
649\end{array}$ & $\begin{array}{l}200-650 \\
350-650 \\
400-750\end{array}$ & $\begin{array}{l}4.3 \\
5.4 \\
7.1\end{array}$ \\
\hline & \multicolumn{2}{|c|}{ Average Q } & 144 & & Range of $n$ & $4-7$ \\
\hline $\begin{array}{l}\text { G727 } \\
\text { (optimum } \\
\text { P\&B) }\end{array}$ & $\begin{array}{l}482.6 \\
551.6 \\
620.6 \\
689.5\end{array}$ & $649-704$ & $\begin{array}{l}212 \\
229 \\
254 \\
267\end{array}$ & $\begin{array}{l}704 \\
677 \\
649 \\
593\end{array}$ & $\begin{array}{c}250-700 \\
450-700 \\
550-900 \\
800-1200\end{array}$ & $\begin{array}{c}7.8 \\
11.4 \\
14.9 \\
15.7\end{array}$ \\
\hline & \multicolumn{2}{|c|}{ Average $Q$} & 240 & & Range of $n$ & $7-16$ \\
\hline
\end{tabular}




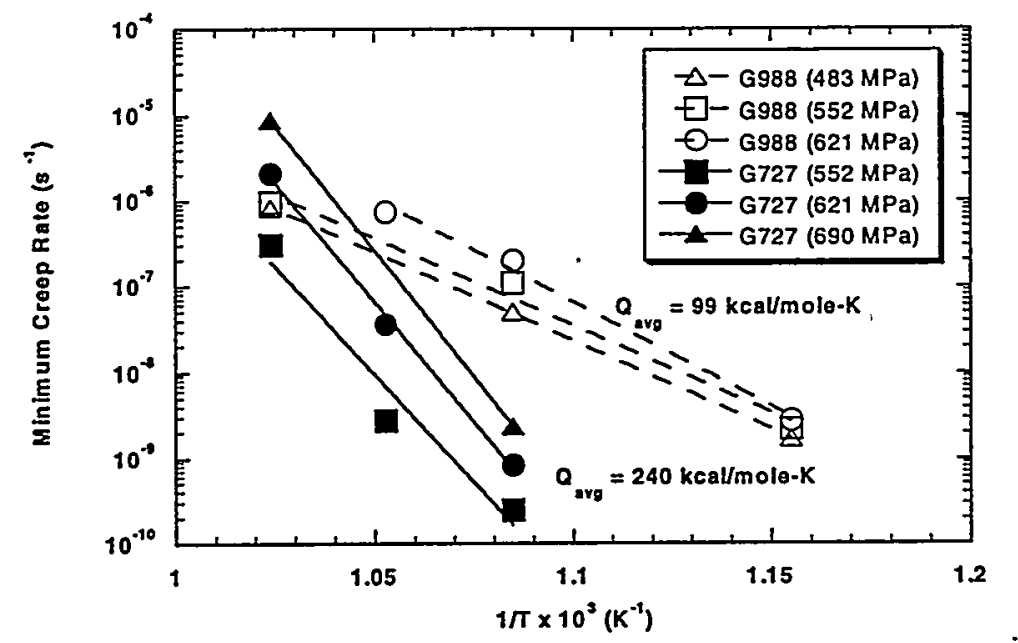

Fig. 3. Determination of activation energies, $Q$, for the high-purity $G 988$ and $P / B-$ modified G727 alloys.

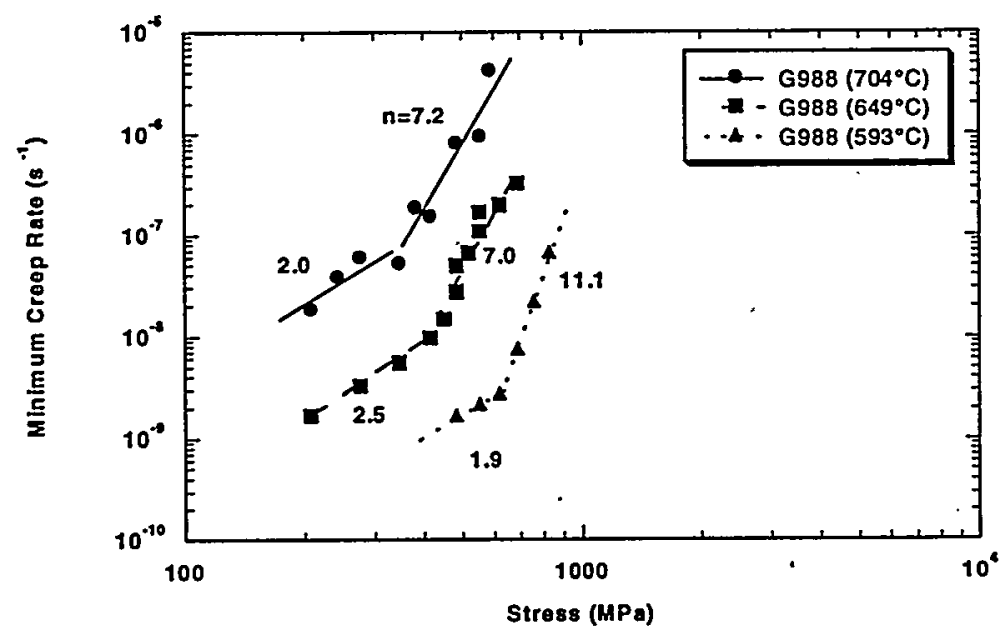

Fig. 4. Determination of stress exponents, $n$, for the high-purity G988 alloy.

from numbers which indicate a dislocation-controlled type of creep mechanism at lower stresses $(n=2-3)$ to numbers which suggest strengthening through some kind of pinning mechanism at the higher stresses $(n=7-11)$. In the microalloyed $G 727$ alloy, stress exponents ranged from 8 to 16 at all stresses tested, and there was no indication of a transition in $\mathrm{n}$ at the lower stresses as was observed in the high-purity alloy. The exponent data for the commercial G457 alloy was somewhat in between the high-purity and microalloyed data $(n=4-7)$ and also showed no indication of a shift in the $n$-values. This data, together with the much higher activation energy for the G727 alloy, suggests that the increased creep life of the modified G727 alloy is due to some kind of pinning 
mechanism, and that, compared to the high-purity alloy, this pinning mechanism remains the controlling mechanism at lower creep stresses with the addition of $\mathrm{P}$ and $\mathrm{B}$.

At this time the possible mechanisms producing the improvement in alloy 718 with optimum additions of $\mathrm{B}$ and $\mathrm{P}$ are still being studied and evaluated in terms of the experimental data. Cao et al. [1] have shown that improved creep-rupture properties can be produced with either $\mathrm{B}$ or $\mathrm{P}$ additions, although the greatest improvement is attained with both additions working in a complementary fashion. There is ample evidence that the strengthening mechanism involves the grain boundaries. It has long been known that $B$, because of its small size and low solubility in the $\gamma$ and $\gamma^{\prime}$ phases, segregates to grain boundaries where it fills vacancies, preventing segregation of harmful elements [15-18]. Recent results using Auger and atom probe analyses have shown that $P$ also segregates to grain boundaries in alloy 718 and in other $\mathrm{Ni}$ - based superalloys $[3,6,8,19]$. Cao et al. have also shown that the effect of $\mathrm{P}$ and $\mathrm{B}$ on creep life is alloy specific; in alloy $718, \mathrm{P}$ and $\mathrm{B}$ act synergistically to improve creep life, while in Waspaloy, $\mathrm{P}$ is detrimental and only additions of $\mathrm{B}$ result in improved creep resistance [1]. This suggests that the beneficial effect of $P$ in alloy 718 may relate to one or more of the microstructural features that are present in alloy 718 but not in Waspaloy (e.g., the $\delta$ or $\gamma$ " phases or the grain boundary denuded zones). Other possible mechanisms producing improved creep resistance with the addition of $\mathrm{P}$ and $\mathrm{B}$ include some kind of interaction of $\mathrm{P}$ and/or $\mathrm{B}$ atoms with precipitates, vacancies, or dislocations in the matrix. However, any study of the effect of $P$ and/or $B$ on the energy or mobility of dislocations or vacancies will be very difficult and will require indirect means of investigation, since few of these features are observed in specimens after creep testing at temperatures as high as those used in the current study [6].

The creep activation energies and exponents presented in this study suggest that a pinning mechanism is producing the improved strength in the P/B-modified alloy. However, those analyses were performed using a simple Arrhenius equation and did not take into consideration the back stress on the dislocations during creep or any change in the shear modulus with changes in test temperature or alloy composition. Such an in-depth analysis has been performed on a commercial-grade alloy 718 by Chaturvedi and Han [20]. Their results show a shift in the creep exponent values, similar to the results presented in this paper for the high-purity alloy, with n values of 1-1.5 at low stresses or temperatures and values of 5-6 at higher stresses or temperatures. They interpret their data as indicating a change from linear or diffusional creep to dislocation power law creep at the higher stresses or temperatures. Their activation energy of 264 $\mathrm{kJ} / \mathrm{mole}$ ( $64 \mathrm{kcal} / \mathrm{mole}$ ) is also lower than the value of $144 \mathrm{kcal} / \mathrm{mole}$ determined in this 
study for the G457 commercial-grade alloy. Some of this difference may be due to slight differences in compositions between the two commercial alloys, but the correction for the shear modulus and back stress should contribute significantly to the difference.

\section{Waspaloy}

Experimental Procedures - Five microalloyed Waspaloys, with Allvac designations and compositions as shown in Table IV, were fabricated as described above for alloy 718 . The wrought bars were then given the following heat treatment: a solution treatment at $1019^{\circ} \mathrm{C}$ for $4 \mathrm{~h}$ followed by a water quench, aging at $843^{\circ} \mathrm{C}$ for $4 \mathrm{~h}$ followed by an air cool, aging at $760^{\circ} \mathrm{C}$ for $16 \mathrm{~h}$ followed by an air cool to room temperature. G752-2 and WB74 are typical of current commercial alloys; G757-1 is a high purity alloy containing essentially no $\mathrm{P}$ or $\mathrm{B}$; G766-2 has the highest amount of $\mathrm{P}$ and $\mathrm{B}$ of the alloys studied, while alloy G949-1 has a similar amount of B but very low P.

Creep-rupture specimens with a gage $3.18 \mathrm{~mm}$ in diameter and $17.8 \mathrm{~mm}$ in length were machined from the as-heat-treated bars and tested without further heat treatment.' Creep rupture tests were conducted in air using lever-arm creep machines with either a 5:1 or 20:1 load ratio. Tests were conducted at various stresses at temperatures of $649\left(1200^{\circ} \mathrm{F}\right), 732\left(1350^{\circ} \mathrm{F}\right), 760\left(1400^{\circ} \mathrm{F}\right)$, and $815^{\circ} \mathrm{C}\left(1499^{\circ} \mathrm{F}\right)$. The test data

\begin{tabular}{|c|c|c|c|c|c|}
\hline \multicolumn{6}{|c|}{ Table IV. Chemical Compositions and Grain Sizes of Modified Waspaloy } \\
\hline \multirow{2}{*}{ Element } & \multicolumn{5}{c|}{ Chemical Composition (wt\%) } \\
\cline { 2 - 6 } & G757-1 & G766-2 & G949-1 & G752-2 & WB74 \\
\hline Ni & Balance & Balance & Balance & Balance & Balance \\
Cr & 19.75 & 19.74 & 19.72 & 19.72 & 19.81 \\
$\mathrm{Co}$ & 13.48 & 13.47 & 13.43 & 13.46 & 13.40 \\
$\mathrm{Mo}$ & 4.23 & 4.27 & 4.32 & 4.21 & 4.27 \\
$\mathrm{Ti}$ & 2.96 & 2.98 & 3.00 & 2.96 & 3.01 \\
$\mathrm{Al}$ & 1.30 & 1.30 & 1.30 & 1.30 & 1.31 \\
$\mathrm{Fe}$ & 0.07 & 0.09 & 0.08 & 0.07 & 0.06 \\
$\mathrm{Si}$ & 0.01 & 0.01 & 0.01 & 0.01 & 0.01 \\
$\mathrm{C}$ & 0.037 & 0.037 & 0.039 & 0.036 & 0.036 \\
$\mathrm{~S}$ & 0.0006 & 0.0005 & 0.0005 & 0.0006 & 0.0006 \\
$\mathrm{~B}$ & $<0.001$ & 0.011 & 0.014 & 0.006 & 0.005 \\
$\mathrm{P}$ & 0.001 & 0.022 & 0.001 & 0.004 & 0.006 \\
\hline ASTM\# & 10 W/B 6-7 & 9 W/B 6 & 9 & 10 & 9 \\
\hline \multirow{2}{*}{ Grain diam } & & & & & \\
$\mathrm{D}$ ( $\mu$ m) & 7.9 & 10.3 & 10.3 & 7.2 & 11.9 \\
\hline
\end{tabular}


were analyzed as described above to determine rupture lives, minimum creep rates, activation energies, and creep exponents.

Flat tensile specimens with gage dimensions of approximately $12.7 \times 3.2 \times 0.75$ $\mathrm{mm}$ were machined from the wrought bars of alloys G757-1, G766-2, and G949-1. Slow strain rate tensile tests, at temperatures between 600 and $900^{\circ} \mathrm{C}$, were performed on a screw-driven Instron machine at a strain rate of $3 \times 10^{-5} \mathrm{~s}^{-1}$ in a vacuum of $10^{-5}$ torr. The lengths of the specimens were measured before and after testing to determine the percent elongation.

Microstructures of the alloys were studied using optical and scanning electron microscopy (SEM) techniques. Specimens for SEM were metallographically polished through $0.5 \mu \mathrm{m}$ diamond and then were etched in a solution of 4 parts $\mathrm{HCl}$ and 1 part $\mathrm{HNO}_{3}$. Scanning electron microscopy was also used to study the fractures of creeptested and tensile-tested specimens.

Optical Microstructures -- Table IV lists the alloys tested in this study. The alloys included one high-purity alloy (G757-1), two commercial-purity alloys (G752-2 and WB74), one alloy with high boron and high phosphorus (G766-2), and one alloy with high boron but low phosphorus (G949-1). The grain sizes noted in Table IV were determined by Allvac and reflect a banded appearance for both the G757 and G766 alloys. Figures 5 and 6 show the optical microstructures of the alloys tested. All of the alloys had fairly homogeneous microstructures, with some degree of banding, except the high purity G757 alloy. That alloy (Fig. 5) exhibited a duplex microstructure with about $50 \%$ large grains $20-100 \mu \mathrm{m}$ in size and the rest very fine grains of about $10 \mu \mathrm{m}$ or less. Where these bands occurred, they appeared to run for long distances in a direction parallel to the rolling direction of the bars. Optical metallography was performed on four different specimens of G757. In these four specimens, large grains occupied 50$80 \%$ (estimated visually) of the cross sectional area.

The G766-2 alloy, with high $B$ and high $P$ additions, contained a few bands of large grains that made up about $10-15 \%$ of the cross sectional area. The bands were normally no larger than $100-150 \mu \mathrm{m}$ in width.

The high B, low P G949-1 alloy (Fig. 6) had a fairly uniform microstructure with grain sizes of about $10 \mu \mathrm{m}$. Very few bands of large grains were observed in 3 different specimens analyzed. One specimen had no observable bands; the other 2 had about $5 \%$ bands across the cross section.

The two commercial alloys, WB74 and G752-2, each had several bands of large grains across the 3-mm-diameter cross section. These large-grain bands made up about $10 \%$ of the cross section. 

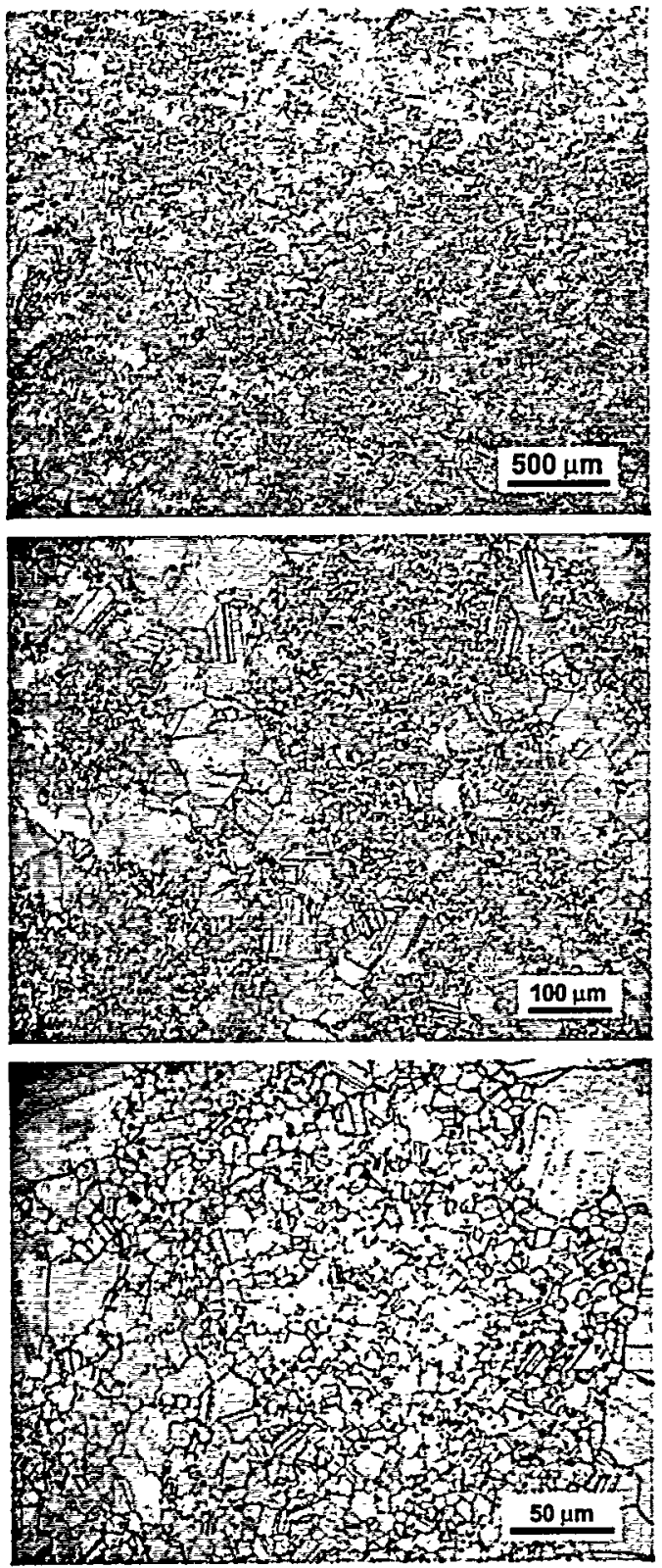

Fig. 5. Optical micrographs of high purity Waspaloy, heat G757-1.
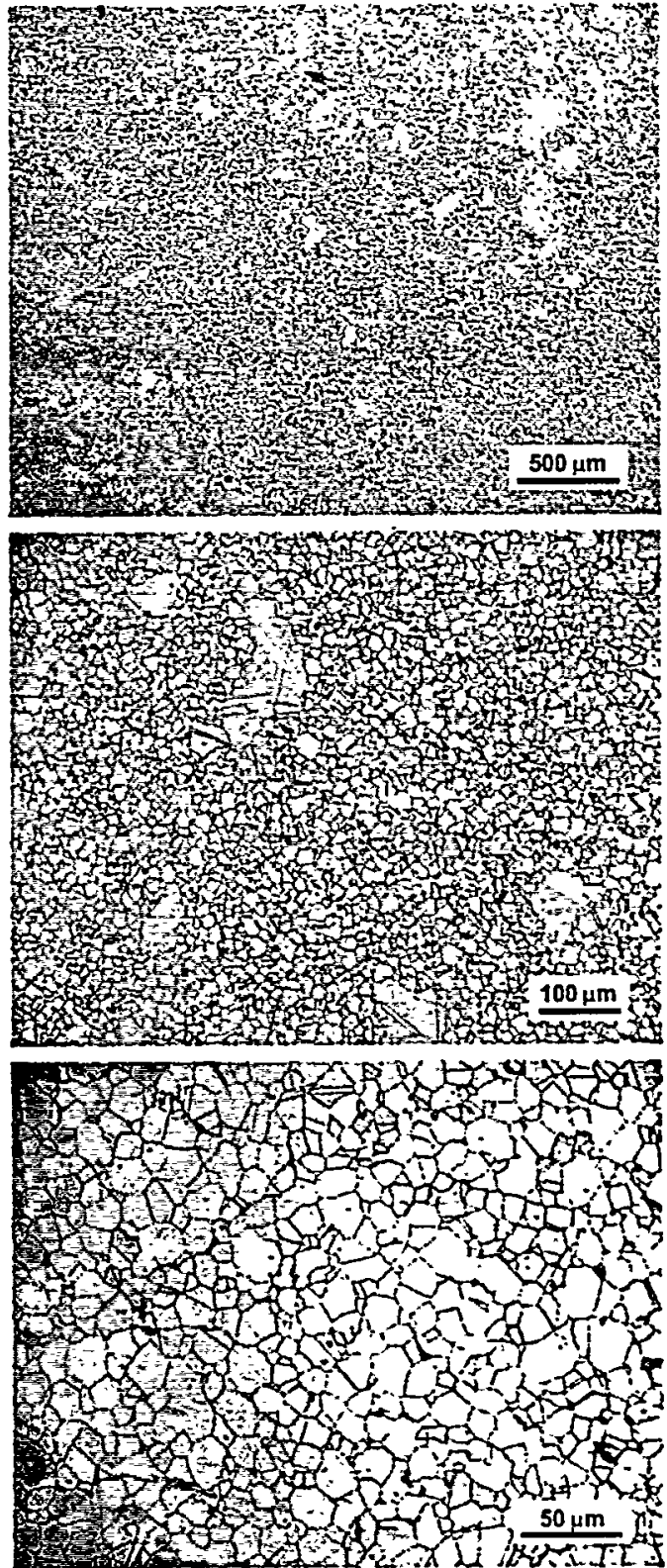

Fig. 6. Optical micrographs of Waspaloy heat G949-1 with high B and low $\mathrm{P}$ concentrations.

Scanning electron microscopy was also used to study the microstructures. Figure 7 shows SEM micrographs of specimens from the high purity G757 alloy. The $\gamma$ ' precipitates were visible in all the alloys with the proper etching. The precipitates along the grain boundaries are rich in $\mathrm{Ni}$ and Mo, while large precipitates in the matrix are rich in Ti and Mo. At this level of magnification, there was no obvious difference in the microstructures of the five alloys that could account for the difference in creep properties. 

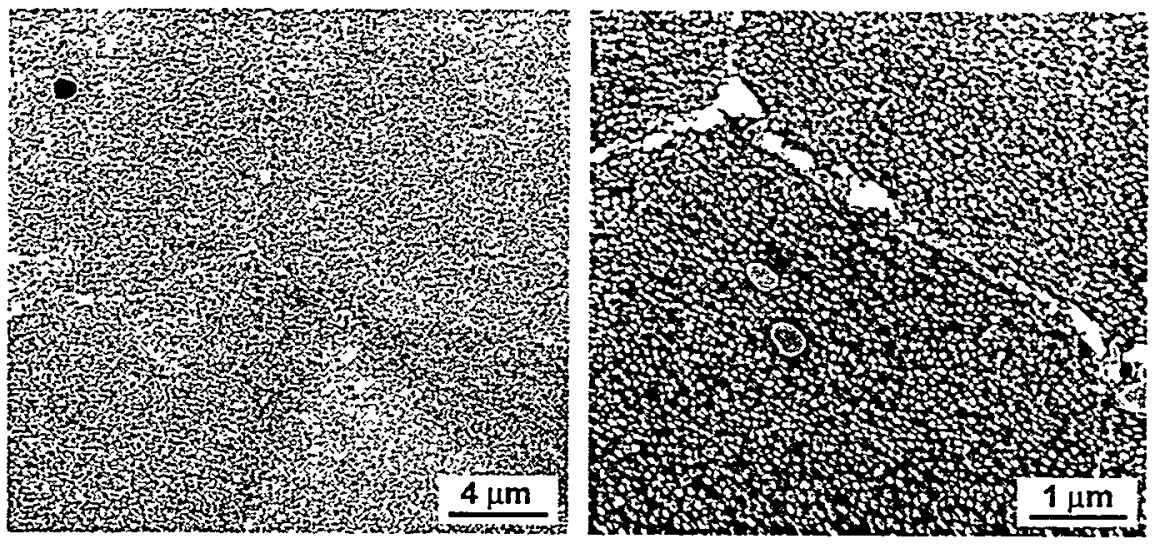

Fig. 7. Scanning electron micrographs of high-purity Waspaloy G757-1.

Creep and Creep-Rupture Testing -- The data for creep tests conducted to failure or near failure are listed in Table V. As noted above, not all of the creep tests performed in this study were allowed to proceed to fracture; instead, many specimens were used to determine several minimum creep rates by incrementally increasing the stress. Typical creep curves, showing creep-strength comparisons for the five alloys, are shown in Figs. 8-10. In all three conditions shown in Figs. 8-10, the G766 alloy, containing high levels of $\mathrm{B}$ and $\mathrm{P}$, was the weakest of the five alloys. At $732^{\circ} \mathrm{C}$, the G766 alloy failed the soonest, while the other four alloys lasted much longer. The reason for the extraordinary strength of the commercial alloy G752 at these test conditions is not understood, but may relate to the lower degree of large-grained banding in the microstructure of this alloy. As the temperature was increased to 760 and then $815^{\circ} \mathrm{C}$, the high B-low P G949 alloy began to separate itself from the other alloys. The curves for the $760^{\circ} \mathrm{C}$ tests, which were only conducted on the high B-high P G766, high B-low P G949, and the high-purity G757 alloys, are shown in Fig. 9. The results show that the G766 specimen elongated much faster than the other two specimens, although it still had not ruptured after $382 \mathrm{~h}$. Both the high purity G757 and high B-low P G949 alloys crept at about the same low rate, but the creep rate of the $\mathrm{G} 757$ alloy increased significantly after about $300 \mathrm{~h}$ and it failed quickly at $388 \mathrm{~h}$. The G949 alloy, on the other hand, had elongated very little and showed no indications of failure after $382 \mathrm{~h}$. At $815^{\circ} \mathrm{C}$, the high B-low P G949 alloy distanced itself further from the other alloys. It fractured at about $154 \mathrm{~h}$, but none of the other alloys lasted longer than 28-30 $\mathrm{h}$.

As shown in Table V and Figs. 8-10, all of the failures in the high-purity G757 alloy occurred at very low ductilities. Inspection of the fractured specimens showed that there was no uniform elongation and no localized necking. In order to determine the fracture mode, fractured specimens were mounted horizontally in epoxy and pol- 


\begin{tabular}{|c|c|c|c|c|c|c|}
\hline Alloy & Spec. \# & $\begin{array}{l}\text { Test Temp. } \\
\left({ }^{\circ} \mathrm{C}\right)\end{array}$ & $\begin{array}{l}\text { Test Stress } \\
(\mathrm{MPa})(\mathrm{ksi})\end{array}$ & Life (h) & $\begin{array}{c}\text { Elongation } \\
(\%)\end{array}$ & $\begin{array}{l}\text { Min. Creep } \\
\text { Rate (s-1) }\end{array}$ \\
\hline $\begin{array}{l}\text { G757-1 } \\
\text { High purity }\end{array}$ & $\begin{array}{l}44 \\
52 \\
53 \\
66 \\
67 \\
75\end{array}$ & $\begin{array}{l}732 \\
760 \\
760 \\
760 \\
760 \\
815\end{array}$ & $\begin{array}{l}75(517) \\
67(462) \\
30(207) \\
20(138) \\
40(276) \\
40(276)\end{array}$ & $\begin{array}{c}7.3 \\
4.8 \\
388.4 \\
380.2 \\
82.4^{\mathrm{a}} \\
26.2\end{array}$ & $\begin{array}{c}10.4 \\
6.0 \\
6.5 \\
5.5 \\
5.0 / 5.7^{c} \\
4.7\end{array}$ & $\begin{array}{l}2.0 \text { e-6 } \\
2.8 \text { e-6 } \\
8.3 \text { e-9 } \\
1.8 \text { e- } 8 \\
8.0 \text { e- } 8 \\
3.3 \text { e- }-7\end{array}$ \\
\hline $\begin{array}{l}\text { G766-2 } \\
\text { high B, } \\
\text { high P }\end{array}$ & $\begin{array}{l}45 \\
54 \\
72 \\
79\end{array}$ & $\begin{array}{l}732 \\
760 \\
815 \\
760\end{array}$ & $\begin{array}{l}75(517) \\
30(207) \\
40(276) \\
40(276)\end{array}$ & $\begin{array}{l}2.65 \\
382^{\mathrm{b}} \\
15.5^{\mathrm{b}} \\
237.9\end{array}$ & $\begin{array}{c}36.5 \\
6.9 / 12.2^{c} \\
26.5 \\
48.3\end{array}$ & $\begin{array}{l}8.3 \text { e- } 6 \\
3.9 \text { e- } 8 \\
2.8 \text { e-7 } \\
9.2 \text { e- } 8\end{array}$ \\
\hline $\begin{array}{l}\text { G752-2 } \\
\text { commer. }\end{array}$ & $\begin{array}{l}46 \\
74 \\
78\end{array}$ & $\begin{array}{l}732 \\
815 \\
760\end{array}$ & $\begin{array}{l}75(517) \\
40(276) \\
30(207)\end{array}$ & $\begin{array}{c}24.6 \\
10.8^{\mathrm{b}} \\
>550^{\mathrm{b}}\end{array}$ & $\begin{array}{l}22.1 \\
16.5 \\
49.3\end{array}$ & $\begin{array}{l}1.1 \text { e- } 6 \\
2.6 \text { e- } 6 \\
2.8 \text { e- } 8\end{array}$ \\
\hline $\begin{array}{l}\text { WB74 } \\
\text { commer. }\end{array}$ & $\begin{array}{l}49 \\
69 \\
70 \\
76 \\
77\end{array}$ & $\begin{array}{l}732 \\
760 \\
732 \\
815 \\
760\end{array}$ & $\begin{array}{l}75(517) \\
40(276) \\
40(276) \\
40(276) \\
30(207)\end{array}$ & $\begin{array}{c}6.9^{\mathrm{b}} \\
408.7 \\
1008.1^{\mathrm{b}} \\
28.1 \\
1050.3\end{array}$ & $\begin{array}{l}26.0 \\
12.5 \\
25.0 \\
47.6 \\
50.6\end{array}$ & $\begin{array}{l}1.5 \mathrm{e}-6 \\
2.8 \mathrm{e}-8 \\
1.2 \mathrm{e}-8 \\
4.9 \mathrm{e}-7 \\
1.4 \mathrm{e}-8\end{array}$ \\
\hline $\begin{array}{l}\text { G949-1 } \\
\text { high B, } \\
\text { low P }\end{array}$ & $\begin{array}{l}50 \\
55 \\
68 \\
71 \\
80\end{array}$ & $\begin{array}{l}732 \\
760 \\
760 \\
815 \\
760\end{array}$ & $\begin{array}{l}75(517) \\
30(207) \\
50(345) \\
40(276) \\
40(276)\end{array}$ & $\begin{array}{c}8.2^{\mathrm{b}} \\
382.3^{\mathrm{b}} \\
165^{\mathrm{a}} \\
153.7 \\
531.9\end{array}$ & $\begin{array}{c}28.3 \\
1.6 / 3.2^{c} \\
5.3 / 25.2^{\mathrm{c}} \\
23.9 \\
34.2\end{array}$ & $\begin{array}{l}2.8 \text { e- } 6 \\
9.2 \text { e- } 9 \\
3.0 \text { e- } 8 \\
4.7 \text { e-8 } \\
2.1 \text { e- } 8\end{array}$ \\
\hline \multicolumn{7}{|c|}{$\begin{array}{l}{ }^{2} \text { Fractured intentionally in room temperature air. } \\
\text { 'Did not rupture. } \\
\text { cFirst number is chart elongation at end of test; second number is elongation measured from specimen. } \\
\text { In each case, specimens were cooled under load from the test temperature. }\end{array}$} \\
\hline
\end{tabular}

ished and etched using standard metallographic techniques. Figure 11 shows that in the high-purity G757 alloy cracks first appeared along the grain boundaries of the largergrained bands. The separation occurred perpendicular to the loading direction. The small-grained bands served to delay crack propagation. However, since the smallgrained bands composed only up to about $50 \%$ of the cross-sectional area (much less in many specimens), it could not sustain the specimen for very long. The low elongations that were measured in the G757 specimens were reflective of this premature separation along the grain boundaries. Several creep tested specimens, tested at various temperatures and stresses, were metallographically prepared and photographed in this manner and all showed this same fracture mode. 


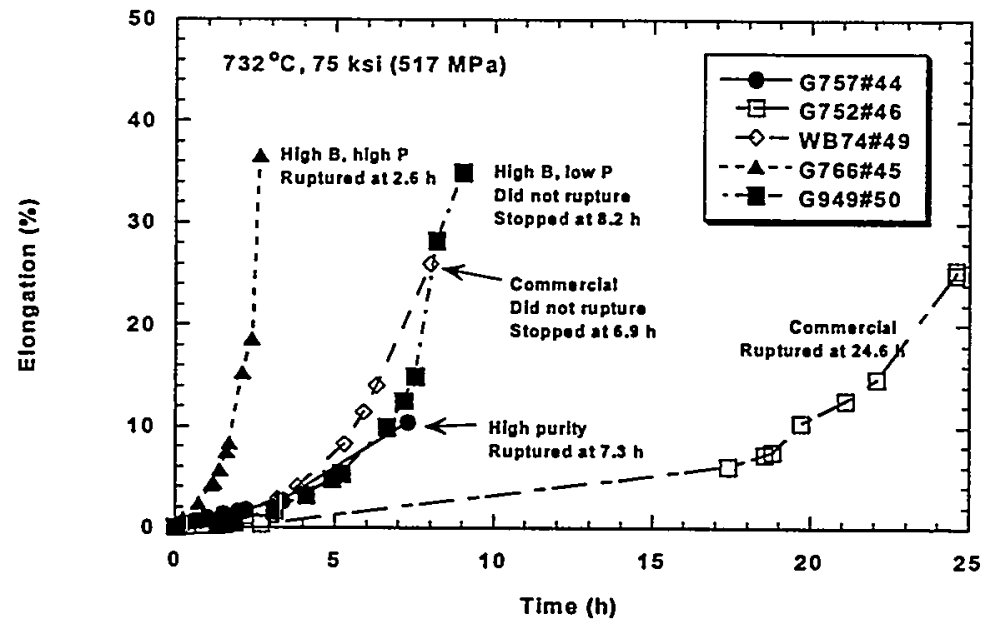

Fig. 8. Creep curves for 5 Waspaloys tested at $732^{\circ} \mathrm{C}$ with an initial stress of $517 \mathrm{MPa}$.

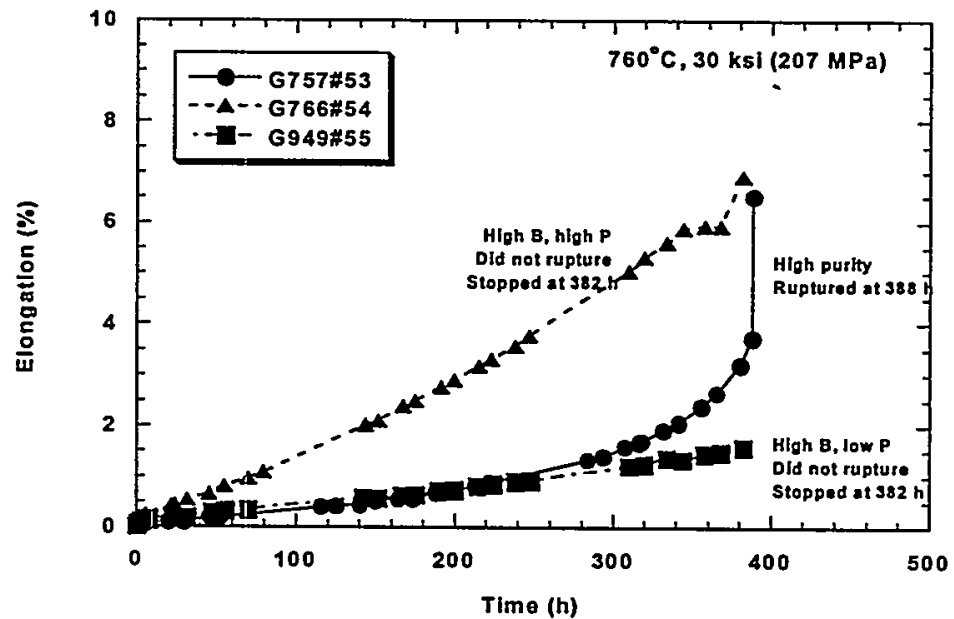

Fig. 9. Creep curves for 3 Waspaloys tested at $760^{\circ} \mathrm{C}$ with an initial stress of $207 \mathrm{MPa}$.

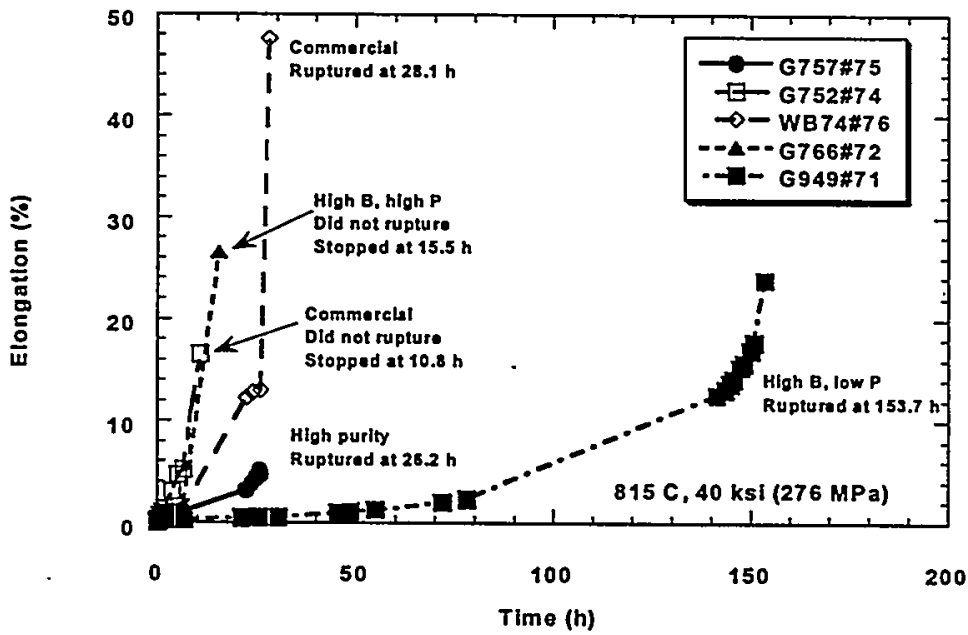

Fig. 10. Creep curves for 5 Waspaloys tested at $815^{\circ} \mathrm{C}$ with an initial stress of $276 \mathrm{MPa}$. 
(a)

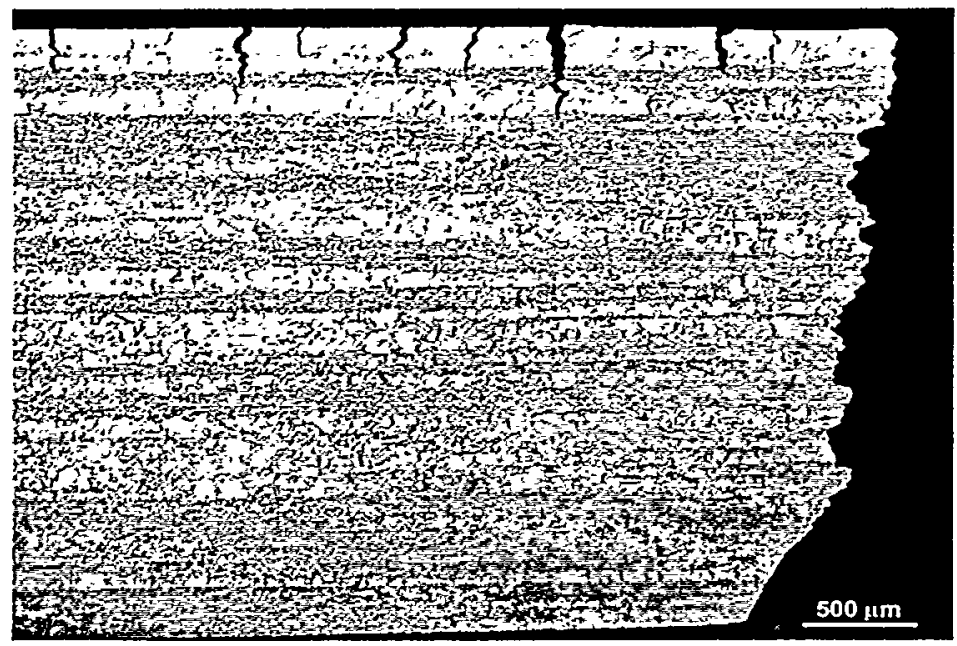

(b)

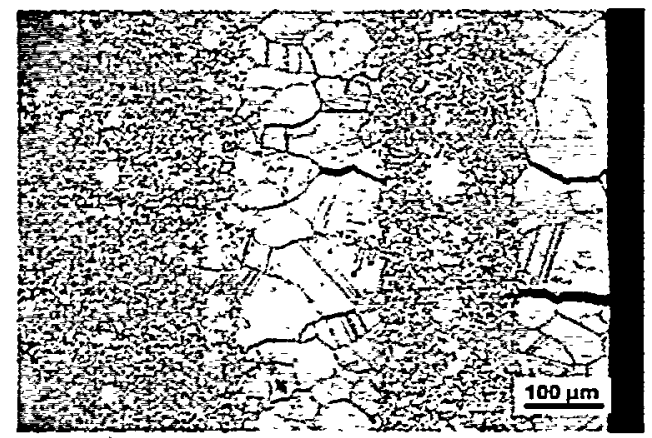

Fig. 11. Low (a) and high (b) magnification optical micrographs showing the fracture morphology of high-purity Waspaloy $\mathrm{G} 757$ creep tested to rupture at $732^{\circ} \mathrm{C}$ with an initial stress of $517 \mathrm{MPa}$.

It was not possible to observe the actual fracture surface of creep-tested specimens because the tests were conducted in air and the fracture surfaces oxidized after failure before they could be removed from the furnace. However, some of the specimens were creep-tested to approximately $5 \%$ chart elongation, then cooled to room temperature under load and fractured in air. Figure 12 shows features of the G757 alloy fractured using this procedure. The fracture surface shows that failure occurred predominantly along grain boundaries, in support of the results from Figs. 11. As is normal for these compositions, many Ni-Mo particles were observed on the grain boundaries.

Figure 13 shows the fractured ends of the high B-high P G766 (also typical of fracture in the commercial-grade $\mathrm{G} 752$ alloy) creep tested at $732^{\circ} \mathrm{C}$ and $517 \mathrm{MPa}(75$ ksi). These two alloys had very little large-grained banding and the bands that were present were much smaller in thickness that those in the high-purity G757 alloy. Creep failure occurred by the formation and coalescence of creep cavities on grain boundaries. 


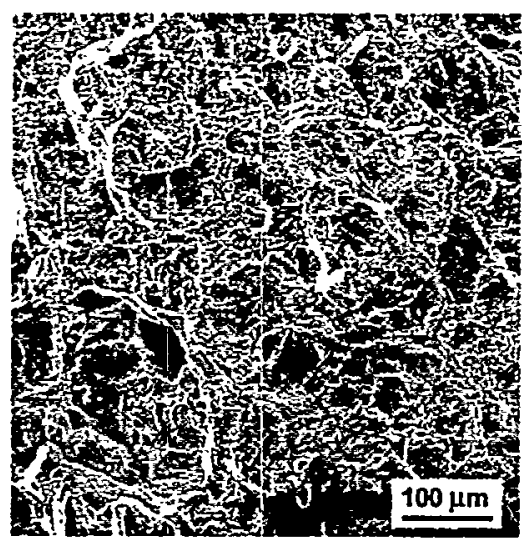

(a)

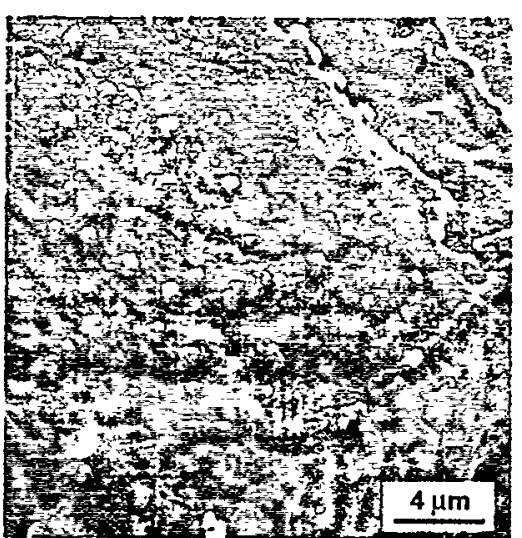

(b)

Fig. 12. Scanning electron fractographs showing (a) intergranular fracture and (b) NiMo particles on the grain boundaries of high-purity Waspaloy G757, ruptured in air at room temperature after creep testing to approximately $5 \%$ at $760^{\circ} \mathrm{C}$ and $276 \mathrm{MPa}$.

(a)

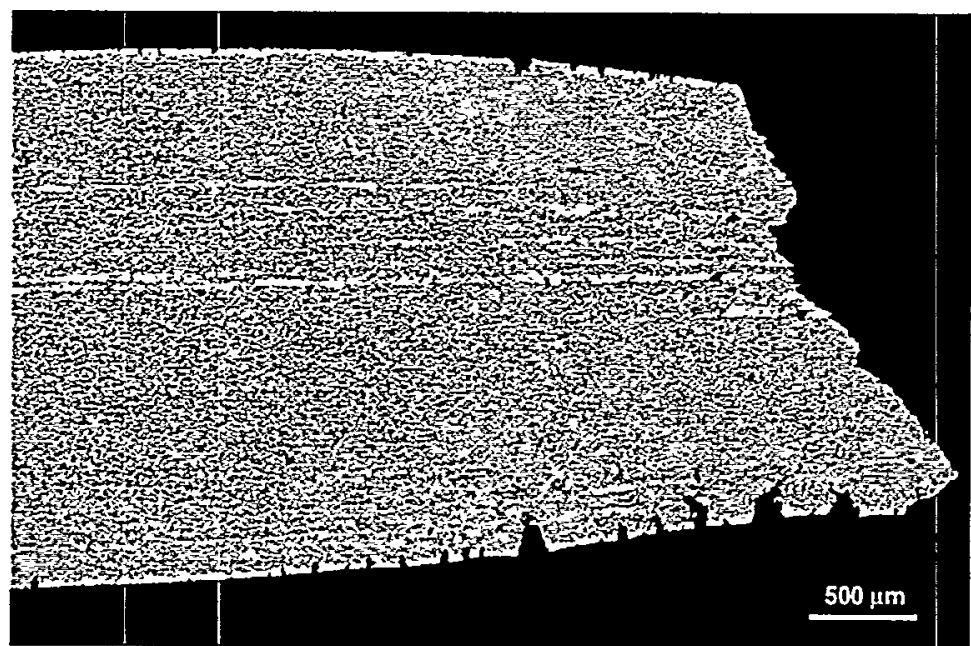

(b)

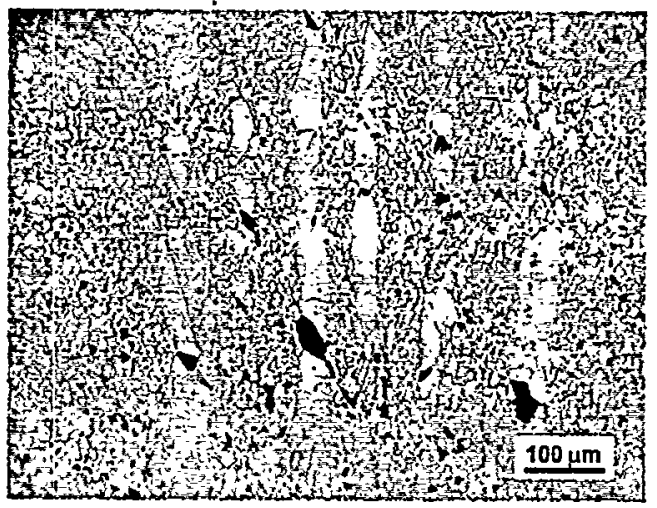

Fig. 13. Low (a) and high (b) magnification optical micrographs showing the fracture morphology of Waspaloy G766 containing high B and high P concentrations creep tested to rupture at $732^{\circ} \mathrm{C}$ and $517 \mathrm{MPa}$. 
A few wedge-shaped cracks were observed on grain boundaries in the large-grained bands, but because these bands were not very wide the cracks did not grow to become the major failure mode as was observed in alloy G757. The commercial-grade WB74 and high B-low P G949 alloy specimens used for the $732^{\circ} \mathrm{C}$ tests continued to elongate and reached the extension limit of the machine's lever arm without failure. Both were very near failure, had began to neck locally, and many surface cracks were visible in the necked region.

The failure mode of the high B-low P G949 alloy was studied using the ruptured specimen tested at $815^{\circ} \mathrm{C}$ and $276 \mathrm{MPa}(40 \mathrm{ksi})$. The corresponding micrographs of its fracture indicated that its basic failure mode was similar to those of all the other alloys except G757. Where large-grained bands were present, some wedge-shaped cracks were visible. But, because the bands were narrow, these did not propagate into the finer-grained regions. Failure was by formation and coalescence of creep cavities on grain boundaries. A specimen fractured at room temperature in air after creep straining to $5 \%$ elongation at $760^{\circ} \mathrm{C}$ and $345 \mathrm{MPa}(50 \mathrm{ksi})$ showed a ductile dimple failure mode (see Fig. 14). It is worth noting that, although this specimen was tested to a creep elongation of $\sim 5 \%$, the final elongation of this G949 specimen was determined to be $25.2 \%$. So this specimen showed significant ductility as it was cooled to room temperature under the load. In contrast, the G757 specimen that was cooled to room temperature under load had a final elongation of only $5.7 \%$.

Using the Arrhenius equation, the activation energies for creep, $Q$, and the stress exponents, $\mathrm{n}$, were determined. For the five alloys used in this study, the activation

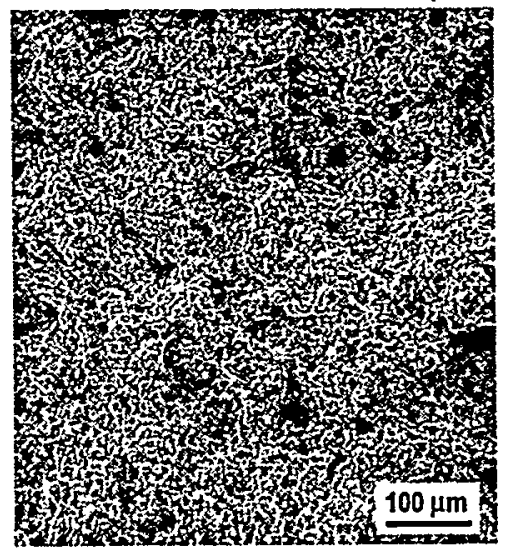

(a)

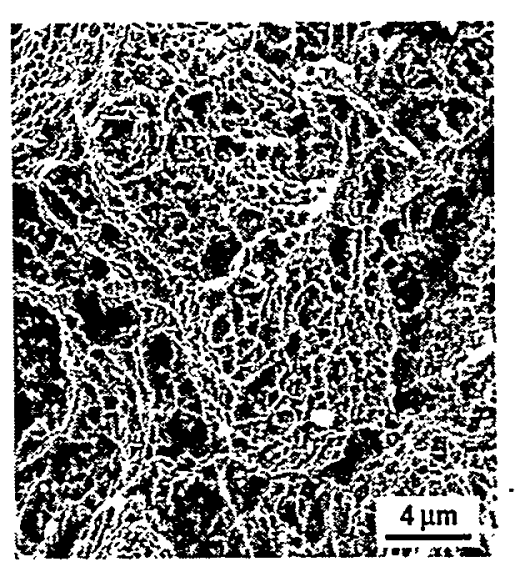

(b)

Fig. 14. Low (a) and high (b) magnification scanning electron fractographs showing the ductile-dimple failure mode of Waspaloy G949 containing high B and low P concentrations, ruptured in air at room temperature after creep testing to approximately $5 \%$ at $760^{\circ} \mathrm{C}$ and $345 \mathrm{MPa}$. 
energy for creep was determined at a stress of $276 \mathrm{MPa}$ ( $40 \mathrm{ksi})$. The results are presented in Fig. 15. The activation energies for the two commercial alloys, WB74 and G752, were determined to be approximately 130 and $114 \mathrm{kcal} / \mathrm{mole}$, while the high purity G757, high B-high P G766, and high B-low P G949 alloys all had Q values of about $60 \mathrm{kcal} / \mathrm{mole}$. For all the alloys, the measured values for the creep activation energy are within the range of reported values for the activation energy for self diffusion in other Ni-based superalloys [10] and is higher than the activation energy for self diffusion in pure nickel [11,12] (as would be expected in alloys compared to pure metals). At this time, the reason for the difference in $\mathrm{Q}$ values between the commercial alloys and the others is not clear. There is no correlation with composition that can explain the difference. The number of data points was low and the scatter in the data points for the commercial alloys was greater. It is possible that with more data points, the line fits for the five alloys will be more comparable.

Although the Arrhenius equation can be used to suggest possible mechanisms controlling creep deformation [13,14], individual creep regimes can be difficult to pin down in complex alloy systems. The five alloys of this study varied only slightly in the level of the two minor alloying additions $\mathrm{P}$ and $\mathrm{B}$. It was not known if these small differences would produce a detectable effect on the creep exponents and activation energies. Figures 16(a) and (b) show creep exponents determined for the five alloys of this study at temperatures of 732 and $760^{\circ} \mathrm{C}$, respectively. There was not much difference evident for the data at $732^{\circ} \mathrm{C}$; all the alloys had creep exponents between 5.5 and 8 .

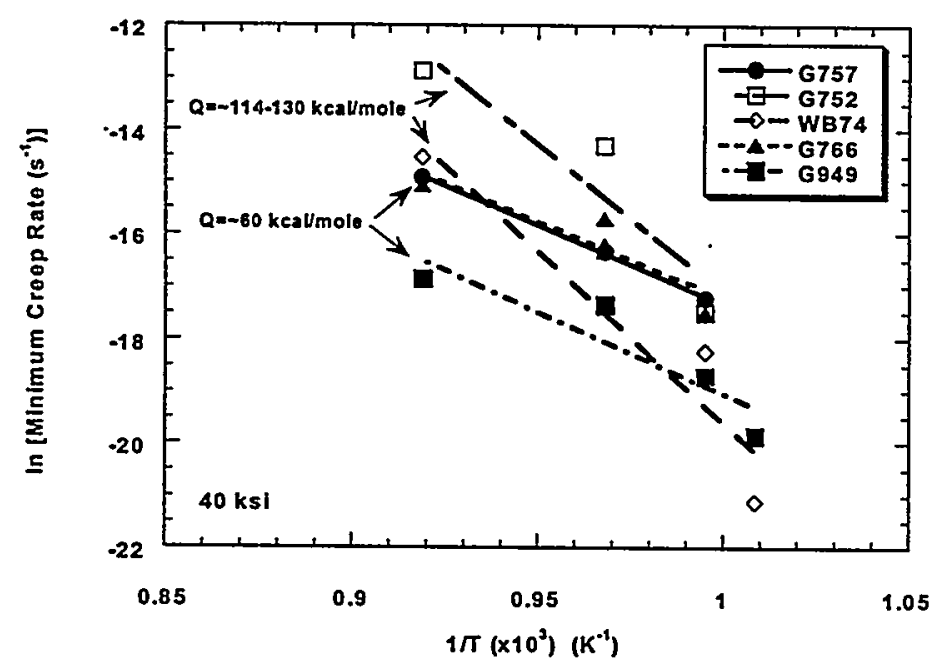

Fig. 15. Temperature versus logarithm of minimum creep rate for the five Waspaloys included in this research. The activation energy for creep was derived from the slope of the lines. 

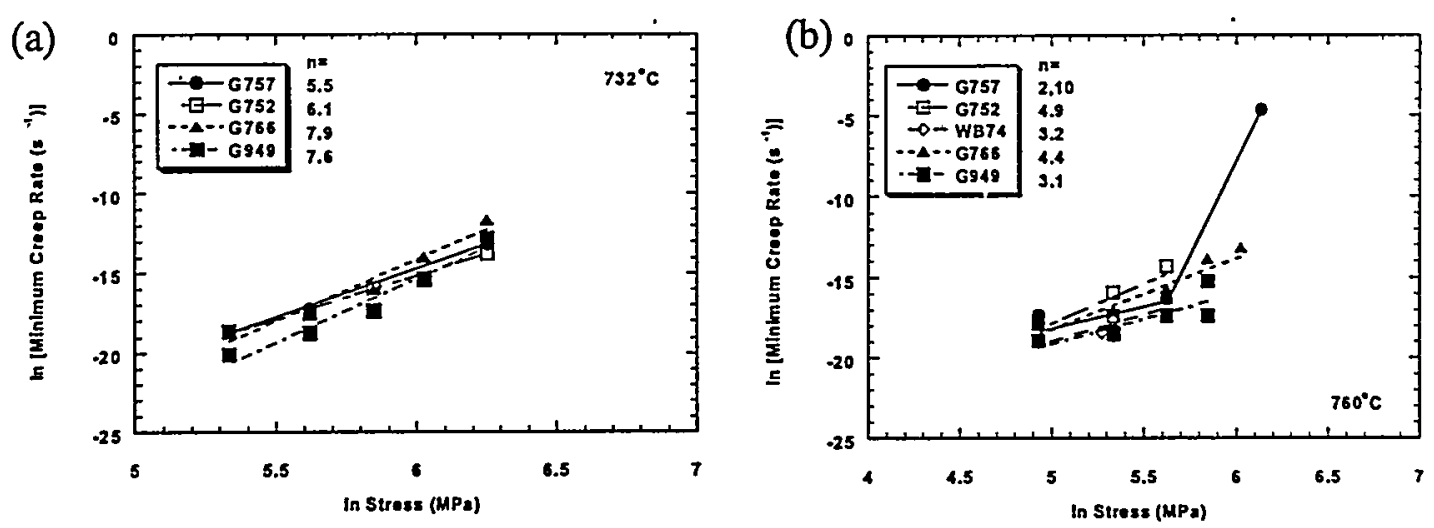

Fig. 16. Plots of flogarithm stress versus logarithm minimum creep rate for Waspaloys creep tested at (a) 732 and (b) $760^{\circ} \mathrm{C}$. The slopes of the lines determine the creep exponent $\mathrm{n}$.

Likewise, limited tests at a lower temperature of $649^{\circ} \mathrm{C}$ showed no tendency for a difference in creep exponents for the high B-low P G949 and the commercial-grade WB74 alloys. As shown in Fig. $16 \mathrm{~b}$, at $760^{\circ} \mathrm{C}$ all the alloys showed $\mathrm{n}$-values between 2 and 5; the correlation factors for the line fits of the data were above $85 \%$. However, the stress exponent data for the high-purity G757 alloy showed a tendency for a shift at a stress of about $276 \mathrm{MPa}(40 \mathrm{ksi})$ from low $n$ numbers $(\mathrm{n}=1.5-2)$ to $\mathrm{n}>10$.

Slow-Strain-Rate Tensile Testing - Slow-strain-rate tensile tests, as described in the experimental procedures, were performed on specimens machined from the G757, G766, and G949 alloy bars. The results are shown in Table VI. Each of these data points represents only one test. Figure 17 shows the variation of rupture ductility with testing temperature for these three alloys. The high-purity G757 alloy had low tensile elongations at all temperatures tested, while the G949 and G766 alloys, both of which contain high levels of $B$, had much higher ductilities. Note that these curves suggest a strong correlation between the presence of $B$ in the alloy and the tensile elongation. The correlation between the presence of $\mathrm{P}$ and elongation is less clear.

\begin{tabular}{|c|c|c|c|c|c|c|c|c|c|}
\hline \multicolumn{6}{|c|}{ Table VI. Slow-Strain-Rate Tensile Properties of modified Waspaloy } \\
\hline \multirow{3}{*}{$\begin{array}{c}\text { Temperature } \\
\left({ }^{\circ} \mathrm{C}\right)\end{array}$} & \multicolumn{3}{|c|}{ G949-1 } & \multicolumn{3}{c|}{ G757-1 } & \multicolumn{3}{c|}{ G766-2 } \\
\cline { 2 - 10 } & YS & UTS & Elong. & YS & UTS & Elong. & YS & UTS & $\begin{array}{c}\text { Elong. } \\
(\%)\end{array}$ \\
\hline 600 & 944 & 1178 & 30.8 & 789 & 1082 & 11.0 & 977 & 1176 & 22.8 \\
700 & 854 & 854 & 16.6 & 770 & 798 & 4.0 & 776 & 776 & 14.0 \\
800 & 501 & 501 & 16.8 & 415 & 417 & 3.3 & 421 & 421 & 30.0 \\
900 & 163 & 163 & 25.4 & 227 & 227 & 7.2 & & & \\
\hline
\end{tabular}




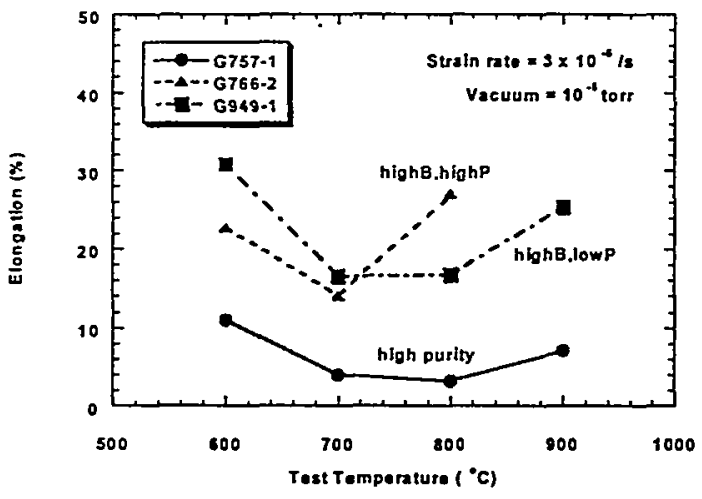

Fig. 17. Tensile elongation versus test temperature for Waspaloys tested in vacuum at a strain rate of $3 \times 10^{-5} \mathrm{~s}^{-1}$.

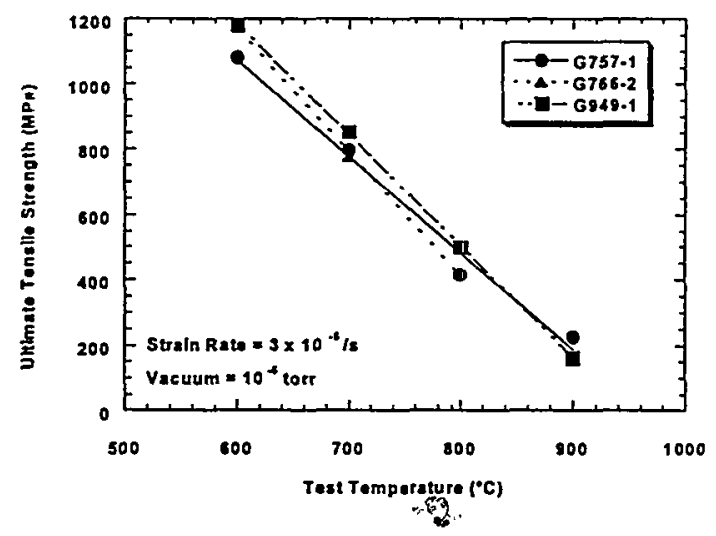

Fig. 18. Ultimate tensile strength versus test temperature for Waspaloys tested in vacuum at a strain rate of $3 \times 10^{-5} \mathrm{~s}^{-1}$.

Figure 18 shows the variation of the ultimate tensile strength (UTS) as a function of testing temperature for the tests shown in Fig. 17. The data show no significant difference in the UTS for the three alloys tested. Therefore, it can be concluded that the differences in ductility seen in Fig. 17 are not due to differences in strength. However, as noted above, the microstructure of the G757 alloy contained bands of large grains, while the G949 and G766 alloys had a more uniform microstructure and average grain sizes of about $10 \mu \mathrm{m}$. Analysis of the fracture modes showed that the G757 specimen fractured in a brittle intergranular mode (see Fig. 19). As in the creep-ruptured specimens, fracture always occurred initially in the large-grained bands, along the grain boundaries and in a direction perpendicular to the load axis. There was no necking visible in any of the G757 specimens. The G949 specimen, on the other hand, failed by formation and coalescence of creep cavities on the grain boundaries. There was extensive elongation of the necked region at failure, which resulted in the extension of some large cavities in the stress direction.

General Discussion - Boron is present in many Ni-based superalloys, usually at levels of 50 to $500 \mathrm{wppm}$. It is reported to segregate to grain boundaries where it prolongs rupture life and improves rupture ductility [21,22]. This strengthening is believed to be due to the slowing down of grain-boundary diffusional processes which contribute to creep deformation. Another hypothesis is that it combines with other elements at the grain boundaries, like $\mathrm{Zr}$, to form borides which take up space and prevent the agglomeration of $\mathrm{M}_{23} \mathrm{C}_{6}$ carbides, also present at grain boundaries [23]. 

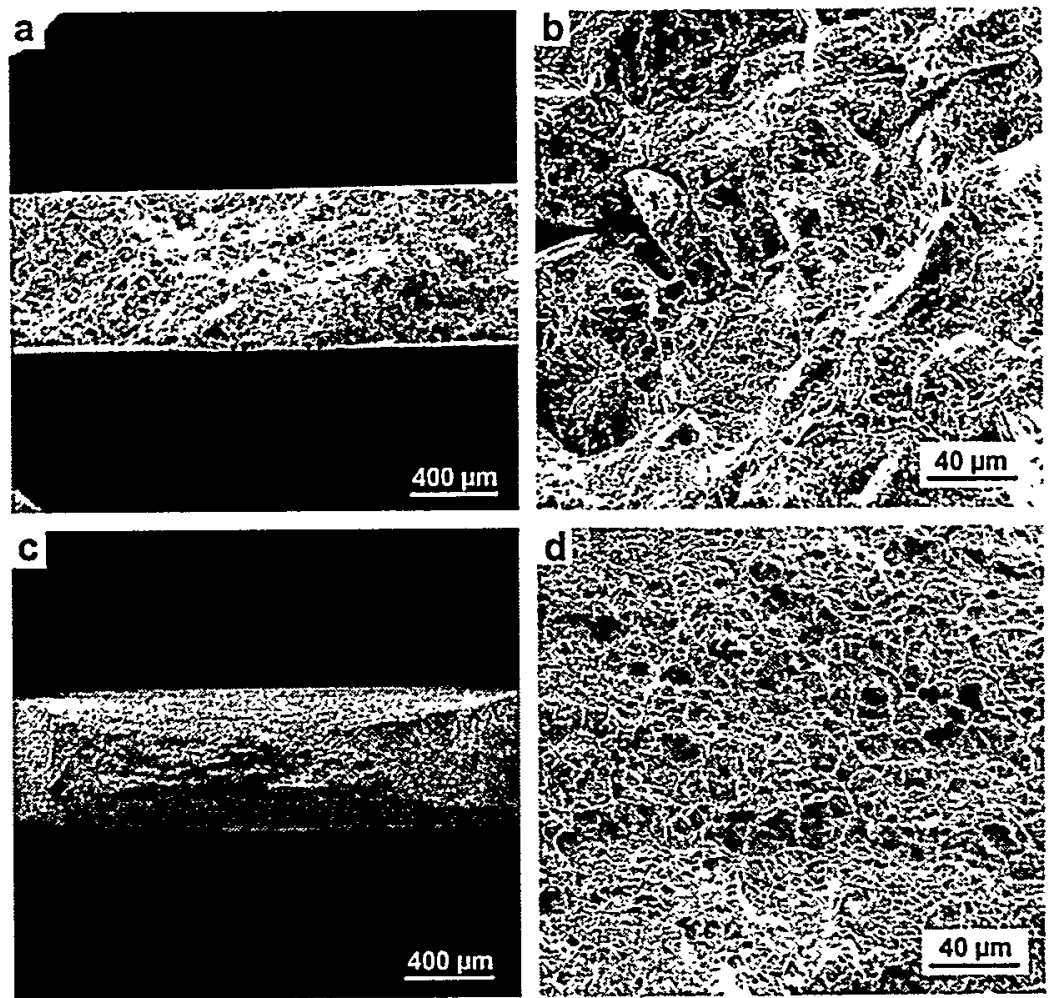

Fig. 19. Scanning electron fractographs showing the fracture modes in $(a, b)$ high-purity' Waspaloy G757 and (c,d) G949 with high B and low P concentrations. Both specimens were tested in tension at $700^{\circ} \mathrm{C}$.

Excessive boron can cause harmful effects through the formation of hard, brittle $M_{3} B_{2}$ borides [21,22].

In Astroloy, a $\gamma / \gamma^{\prime}$-strengthened, nickel-based superalloy similar to Waspaloy, Letellier, et al. [24], using a three-dimensional atom probe called Tomographic AtomProbe, have shown that B and Mo (and to a lesser extent, C) segregate strongly to the $\gamma^{\prime}$ $\gamma$ ' grain boundaries. Along with the enrichment of $\mathrm{B}$ and $\mathrm{Mo}$, they reported a depletion of $\mathrm{Al}, \mathrm{Ti}$, and $\mathrm{Ni}$ (constituents of the $\gamma^{\prime}$ phase) in a 2-nm zone at the grain boundaries.

Contrary to Letellier's work, in an atom probe analyses of alloy 718, Miller et al. $[5,6,8]$ showed that $\mathrm{B}$ and $\mathrm{P}$ both prefer to segregate to the $\gamma / \gamma$ grain boundaries and then to phosphides. They do not segregate to $\gamma / \gamma^{\prime}$ or $\gamma / \gamma^{\prime \prime}$ boundaries. Boron is a more potent grain boundary segregant. Mo was also seen to segregate to $\gamma / \gamma$ grain boundaries and not to $\gamma / \gamma^{\prime}$ or $\gamma / \gamma^{\prime \prime}$ boundaries.

Walsh and Kear [17] used secondary ion mass spectrometry (SIMS) to show that B segregates to grain boundaries in Udimet 700 , a Ni-Cr-Co-based superalloy similar to Waspaloy. Also present at grain boundaries were coarse $\gamma^{\prime}$, fine $(\sim 180 \AA)$ and coarser $(\sim 1200 \AA) \mathrm{M}_{3} \mathrm{~B}_{2}$ precipitates and coarse intragranular $\mathrm{M}_{3} \mathrm{~B}_{2}$ precipitates. 
Xie et al. [19] showed that $\mathrm{P}$ segregates to the grain boundaries and increases the creep lives of alloy $718\left(650^{\circ} \mathrm{C}, 686 \mathrm{MPa}\right)$. It does not affect tensile properties, but it extends the second stage of creep significantly. In $\mathrm{Ni}-\mathrm{Cr}-\mathrm{Fe}$ and $\mathrm{Ni}-\mathrm{Cr}-\mathrm{Fe}-\mathrm{Mo}$ alloys (at $650^{\circ} \mathrm{C}, 150 \mathrm{MPa}$ ) with $\mathrm{Cr}, \mathrm{Fe}$, and $\mathrm{Mo}$ additions similar to alloy 718 , it has no effect on tensile properties, but increases the creep life and ductility in Ni-Cr-Fe-Mo alloys. They suggest an interaction with grain boundary segregants that form precipitates, such as Mo.

Briant [25] studied segregation at grain boundaries in alloy 182 using Auger electron spectroscopy and showed that $\mathrm{P}$ segregates strongly to grain boundaries. This alloy has $\mathrm{M}_{23} \mathrm{C}_{6}, \mathrm{M}_{7} \mathrm{C}_{3}$, and TiC precipitates at the grain boundaries, but none contained $P$. The same $P$ segregation characteristics were reported for Inconel 600 by Guttman, et al. [26], who along with Berkowitz and Kane [27,28] report Auger evidence for a role of $P$ in promoting hydrogen embrittlement of nickel-base and nickel-cobalt-based superalloys.

Cao et al. [1] have shown that improved creep-rupture properties can be produced in alloy 718 with either $B$ or $P$ additions, although the greatest improvement is attained with both additions working in a complementary fashion. It has long been known that $B$, because of its small size and low solubility in the $\gamma$ and $\gamma^{6}$ phases, segregates to grain boundaries where it fills vacancies, preventing segregation of harmful elements [15-18]. Recent results using Auger and atom probe analyses have shown that $\mathrm{P}$ also segregates to grain boundaries in alloy $718[3,6,8,19]$ and in other Ni-based superalloys.

Song et al. [29] recently reported that $P$ additions to alloy 718 result in a refinement of the size and a more uniform distribution of $\delta$-phase particles at the grain boundaries. They propose that the beneficial effect of $\mathrm{P}$ additions on creep properties arises from the inhibition of diffusion along grain boundaries.

Additional research is needed to determine whether any of the above mechanisms are responsible for the observed ductility and strength improvements in Waspaloy.

\section{INVENTIONS}

None. 


\title{
COMMERCIALIZATION POSSIBILITIES
}

\begin{abstract}
Alloy 718
To date, no commercial applications for the B/P-modified version of alloy 718 (designated $718 \mathrm{ER}^{\otimes}$ ) have materialized. Both of the U.S. aircraft engine manufacturers are interested in this technology, but the improvement in life of the modified 718 compared to the standard alloy is not large enough to justify the expense involved in approval. There may still be potential commercialization possibilities in the future, as new performance requirements are being developed today for which the creep requirements for standard 718 are of concern.
\end{abstract}

\section{Waspaloy}

Allvac has developed several areas of interest for the P/B-modified version of the Ni-based superalloy Waspaloy (designated Waspaloy $\mathrm{ER}^{\circledR}$ ). All of these applications apply to situations where problems have been encountered in meeting the required stress rupture life. Substitution of modified Waspaloy $E R^{\circledR}$ has resulted in a substantial improvement in rupture life for the same parts with the result being passed specification requirements. To date, Allvac has manufactured and shipped approximately 100,000 lbs of rectangular bar product. Inquiries for small diameter round bar and large diameter billet have also been received and customer orders for these applications are expected. It is anticipated that this will be ongoing business. Allvac is also attempting to pursuade customers to modify their specifications for higher boron contents which would permit taking full advantage of the P-B effect in this alloy.

\section{PLANS FOR FUTURE COLLABORATION}

At this time, Allvac does not see the need for additional work on these two specific alloys. They are, however, considering the possibility of further modification of alloy 718 to improve its creep performance and high temperature stability. As this effort proceeds, it is possible there may be areas for mutual work in the future. 


\section{CONCLUSIONS}

In alloy 718 , the best improvement in ștress-rupture life is observed when $P$ and $\mathrm{B}$ are present at their respective optimum levels (which are significantly higher than their levels in commercial heats). Rupture ductilities were unchanged, but creep testing showed a decrease in the steady state creep rate of up to ten fold. There was no evidence that the stability of the $\gamma^{\prime}$ or $\gamma^{\prime \prime}$ precipitates changed with $\mathrm{P}$ and $\mathrm{B}$ additions, or that these elements segregated to the particle interfaces (although they did segregate to the grain boundaries). In Waspaloy, the longest stress-rupture life is obtained when B is added at its optimum level but $\mathrm{P}$ is kept at the lowest possible level. At higher $\mathrm{P}$ concentrations (e.g., at the typical P level found in commercial heats of Waspaloy), the beneficial effect of $\mathrm{B}$ is not as great. Unlike in alloy 718 , where fracture is transgranular, fracture in Waspaloy is intergranular. Creep strength was highest in the high-B low-P alloy and lowest in the high-B high-P alloys with the high-purity and commercial-purity alloys falling in between. Interpretation of the trace element effects was complicated by the presence of bands of larger grains in most of the alloys tested. In general, when grain-boundary sliding is the dominant deformation mechanism in creep, fine grain size alloys are weaker than coarse grain size alloys. In the present study, however, the high-purity alloy (with the largest grains) was weaker than the high$B$ low-P alloy with finer grains, suggesting that intra-granular processes of dislocation locking (directly by trace-element atmospheres or indirectly by the trace elements altering the vacancy concentrations) may be more important than grain-boundary sliding. Ductility, which was lowest in the high-purity alloy, could be improved by the addition of $B$, but not by the addition of $B+P$. Since poor ductility and low strength can both be life-limiting factors in high-temperature applications, the high-B low-P modification of Waspaloy is optimal. In alloy 718 , in contrast, ductility did not change much with alloying additions; therefore, the combination of $\mathrm{P}+\mathrm{B}$ which results in highest strength is optimal.

\section{REFERENCES}

1. W. D. Cao and R. L. Kennedy, in Superalloys 1996, TMS Warrendale, PA, 589 (1996).

2. R. L. Kennedy, W. D. Cao, and W. M. Thomas, Adv. Mater. Proc. 149, 33, March 1996. 
3. W. D. Cao and R. L. Kennedy, in Proc. Int. Symp. Superalloys $718,625,706$ and Various Derivatives, ed. E. A. Loria, TMS, Warrendale, PA, 463 (1994).

4. E. P. George and R. L. Kennedy, in Impurities in Engineering Materials, ed. C. L. Briant, Marcel Dekker, Inc., NY, 225 (1999).

5. M. K. Miller, J. A. Horton, W. D. Cao and R. L. Kennedy, J. De Physique IV, C5, 6, 241 (1996).

6. J. A. Horton, C. G. McKamey, M. K. Miller, W. D. Cao, and R. L. Kennedy, in Superalloys 718, 625, 706 and Various Derivatives, ed. E. A. Loria, TMS, Warrendale, PA, 401 (1997).

7. C. G. McKamey, C. A. Carmichael, W. D. Cao, and R. L. Kennedy, Scripta Mater. 38, 485 (1998).

8. S. J. Sijbrandij, M. K. Miller, J. A. Horton, W. D. Cao, and R. L. Kennedy, to be published (1997).

9. W. D. Cao and R. L. Kennedy, pp. 511-20 in Superalloys 718, 625, 706 and Various Derivatives, ed. E. A. Loria, TMS, 1997.

10. J. Helsop, J. Inst. Metals 91, 28 (1962-63).

11. J. E. Dorn, p. 255 in Creep and Recovery, (ASM, Cleveland, OH, 1956).

12. A. J. Reynolds, B. L. Averbach, and M. Cohen, Acta Metall. 5, 29 (1957).

13. F. Garofalo, Fundamentals of Creep and Creep-Rupture in Metals (Macmillan Co., New York, 1965).

14. O. D. Sherby and P. M. Burke, Prog. Mater. Sci. 13, 325 (1968).

15. R. T. Holt and W. Wallace, Intern. Metals Rev. 21, 1-24 (1976).

16. R. F. Decker, p. 147 in Symp. on "Steel Strengthening Mechanisms", Greenwich, CN, Climax Molybdenum Co., 1970.

17. J. M. Walsh and B. H. Kear, Metall. Trans. 6A, 226-29 (1975).

18. J. Kameda and A. J. Bevolo, Acta Metall. Mater. 41(2), 527-37 (1993).

19. X. Xie, X. Liu, J. Dong, Y. Hu, Z. Xu, Y. Zhu, W. Luo, Z. Zhang, and R. G. Thompson, pp. 531-42 in Superalloys 718, 625, 706 and Various Derivatives, ed. E. A. Loria, TMS, 1997.

20. M. C. Chaturvedi and Y. Han, pp. 489-98 in Superalloy 718 - Metallurgy and Applications, edited by E. A. Loria, TMS, Warrendale, PA, 1989.

21. N. S. Stoloff, pp. 371-417 in Alloying, eds. J. L. Walter, M. R. Jackson, and C. T. Sims, ASM International, Materials Park, OH 1988.

22. C. P. Sullivan and M. J. Donachie, Jr., in Section VIII: Nickel-Base Superalloys, of Source Book on Materials for Elevated-Temperature Applications, ASM, 1979 , pp. 250-59, compiled by Elihu F. Bradley.

23. R. F. Decker and J. W. Freeman, Trans. AMME 218, 277 (1960). (1994).

24. L. Letellier, A. Bostel, and D. Blavette, Scr. Metall. Mater. 30(12), 1503-08

25. C. L. Briant, Met. Trans. 19A, 137-43 (1988). 
26. M. Guttman, Ph. Dumoulin, Nguyen Tan-Tai, and P. Fontaine, Corrosion $37,416-25$ (1981).

27. B. J. Berkowitz and R. D. Kane, Corrosion 36(1), 24-29 (1980).

28. R. D. Kane and B. J. Berkowitz, Corrosion 36(1), 29-36 (1980).

29. H. Song, S. Guo, and Z. Hu, Scripta Mater. 41(2), 215-19 (1999). 


\section{INTERNAL DISTRIBUTION}

1. R. A. Bradley, 4500S, 6161

2. E. P. George, $4500 \mathrm{~S}, 6115$

3. J. A. Horton, $4500 \mathrm{~S}, 6115$

4. L. L. Horton, $4500 \mathrm{~S}, 6132$

5. C. T. Liu, $4500 \mathrm{~S}, 6115$

6. A. J. Luffman, 5002,6416

7-9. C. G. McKamey (3), 4500S, 6115

10. T. L. Payne, 5002, 6416

11. T. M. Rosseel, $4500 \mathrm{~S}, 6138$

12. C. A. Valentine, 111 UNV, 6429

13-14. Laboratory Records (2), 4500N, 6285

\section{EXTERNAL DISTRIBUTION}

15. S. J. Barish, Department of Energy, SC-32, 19901 Germantown Rd., Germantown, MD 20874-1290

16. W. D. Cao, Allvac, an Allegheny Teledyne Co., 2020 Ashcraft Avenue, P.O. Box 5030, Monroe, NC 28111-0530

17. P. L. Gorman, DOE-ORO, ORNL Site Office, P.O. Box 2008, Oak Ridge, Tennessee 37831-6269

18. R. L. Kennedy, Allvac, an Allegheny Teledyne Co., 2020 Ashcraft Avenue, P.O.

Box 5030, Monroe, NC 28111-0530

19. W. M. Polansky, Department of Energy, SC-32, 19901 Germantown Rd., Germantown, MD 20874-1290

20-21. Office of Scientific and Technical Information (2), P.O. Box 62, Oak Ridge, TN 37831

22. Work for Others Office, DOE-ORO, MS G209 